\title{
INHABITANTS' PERCEPTIONS OF THE CENTRAL SQUARES AND QUALITY OF LIFE IN CLUJ-NAPOCA, ROMANIA
}

\author{
Oana-Ramona ILOVAN \\ Babeş-Bolyai University, Cluj-Napoca, Faculty of Geography, \\ Department of Regional Geography and Territorial Planning, ROMANIA \\ ilovanoana@yahoo.com

\section{Emanuel-Cristian ADOREAN*} \\ Babeş-Bolyai University, Cluj-Napoca, Faculty of Geography, \\ Centre for Research on Settlements and Urbanism, ROMANIA \\ adorean.ec@gmail.com; *corresponding author

\section{Viorel GLIGOR} \\ Babeş-Bolyai University, Cluj-Napoca, Faculty of Geography, \\ Department of Regional Geography and Territorial Planning, ROMANIA \\ viorel.gligor@ubbcluj.ro
}

\section{Zoltan MAROŞI}

Babeş-Bolyai University, Cluj-Napoca, Faculty of Geography, Centre for Research on Settlements and Urbanism, ROMANIA zoltan_marosi@yahoo.de

\section{Cristina-Georgiana VOICU}

Romanian Geographical Society, lași Subsidiary, ROMANIA voicucristina2004@yahoo.fr

\section{Maria Eliza DULAMĂ}

Babeş-Bolyai University, Cluj-Napoca, Faculty of Psychology and Sciences of Education, ROMANIA dulama@upcmail.ro

\author{
Alexandru-Sabin NICULA \\ Babeş-Bolyai University, Cluj-Napoca, Faculty of Geography, Centre for Research on Settlements and Urbanism; \\ National Institute for Economic Research "Costin C. Kiriţescu", Romanian Academy, Bucharest, ROMANIA \\ sabin.nicula@gmail.com \\ DOI: http://doi.org/10.23740/TID220185
}

\section{ABSTRACT}

We live in an era in which public life within the urban space is in a profound crisis. The urban and economic development, corroborated with the technological advances, often determine public space to be replaced by remote social interactions. Thus have appeared more and more private spaces (i.e. commercial centres), culminating with an increasingly restricted and timid use of the public space that places under the sign of uncertainty the citizens' right to the city. In this study, we aimed at realising a territorial diagnosis of the squares in the central area of Cluj-Napoca, analysing the degree of functionality of the urban elements, their current role based on users' perceptions and experience, as well as the assessment of the cultural landscape's aesthetic. Methodology included a questionnaire survey, direct and participatory observation, thematic photography, cartographic mapping, urban inventory, and territorial diagnosis. Results showed that the historical squares in the central Cluj-Napoca area were different in form, profile, size and structure, and in functional attributes. In addition, there has been a change in the functions of squares, along with the evolution of the city, from the economic function to the recreational and cultural one. Moreover, we realised an analysis and typology of the cultural landscapes of the urban public space in Cluj-Napoca. These research results enabled us to propose a series of actions which could reduce or eliminate territorial malfunctions, providing results for the decision-making process and for other researchers wishing to explore more this topic. 


\section{INTRODUCTION: PROBLEM DESCRIPTION AND MAIN RESEARCH QUESTION}

In 2012, a quality of life survey was carried out at European level within the Urban Audit programme. All the European Union countries, Turkey, Iceland, Norway, and Switzerland were involved, aggregating a total number of 79 cities (the most important and representative of the continent in their vast majority) and, moreover, four metropolitan areas (Athens, Paris, Lisbon, and Manchester metropolitan areas). The survey consisted in running a questionnaire by telephone to a sample of about 500 people (between 497 and 522 for each city, summing up a total of 41,000 persons), by national languages in all previously mentioned countries, conducted by TNS Political \& Social, at the request of the European Commission, DirectorateGeneral for Regional and Urban Policy. In case of Romania, the cities of Cluj-Napoca and Piatra Neamț were selected, alongside the capital city (European Commission, 2013, p. 5).

The indicators taken into consideration included public transport, medical services, sports and cultural facilities, the current state of the streets and residential buildings, public spaces (plazas, squares, and pedestrian areas), green areas, shopping facilities, educational infrastructure, air quality, harmful noise levels, level of cleanliness, or life satisfaction in those cities, ease of finding a job, foreigners' presence in the city and their integration level, safety level, administrative services, the strive against climate change, trust level in citizens and authorities, ease of renting a house at reasonable prices, as well as personal considerations regarding workplaces, financial status, life in general, and the living area (European Commission, 2013, p. 6).

Concerning the population's general satisfaction about their living standard, the city of ClujNapoca ranks the $8^{\text {th }}(75 \%$ very satisfied, $21 \%$ quite satisfied, $3 \%$ rather unsatisfied, $1 \%$ totally unsatisfied), being overtaken by Aalborg ( $1^{\text {st }}$ place), Hamburg, Groningen, Copenhagen, Oslo, Zurich, and Amsterdam (European Commission, 2013, p. 17), but ahead of a series of world-class cities such as Paris, Madrid, Rome, and Berlin. Bucharest is ranked the $72^{\text {nd }}$, while Piatra Neamț is ranked the $19^{\text {th }}$ (European Commission, 2013, p. 19). With reference to the residents' satisfaction level about the public space, Cluj-Napoca is ranked only the $52^{\text {nd }}$ (20\% very satisfied, $57 \%$ quite satisfied, $18 \%$ rather unsatisfied, $4 \%$ totally unsatisfied, $1 \%$ do not know/do not answer), however above Bucharest - ranked the $79^{\text {th }}$ (European Commission, 2013, p. 50).

Considering this background information, during recent research, we focused on the residents' satisfaction level about the public space in Cluj-Napoca, deciding that more detailed analysis was necessary in order to identify the causes of most of the citizens' dissatisfaction and finding the best solutions to change this perception in the near future. Therefore, we started from a general research question: What are the citizens' perceptions of Cluj-Napoca city centre as a well-defined functional space? Answers to this question are valuable to identify and promote urban regeneration actions (a hot topic on the agenda of many cities in Romania, to be approached in a forthcoming research paper).

We thus approached Cluj-Napoca by investigating the general features of the central public space, of the city centre squares with a thorough analysis of their present features and functions, while also taking into account the respondents' perceptions of the public spaces and quality of life, concluding our research with a typology of the hybrid places and cultural landscapes, as products of the urban evolution characteristic of this city.

We emphasize that Cluj-Napoca has a genuine inherited urban landscape, given the characteristics of urban landscapes to preserve the past legacy at different levels and aspects. The core structure of Cluj-Napoca historic centre displays the influences of a two thousand years history, distinctly overlaid during independent ages, resulting in a cultural stratification 
reflected to a certain extent by the current urban configuration. Although there are no completely preserved urban structures dating from the Ancient Roman period, except for several isolated remains discovered during excavations and renovations, it is notable that this place boosted its significance by re-establishing its medieval settlement on the Roman ruins.

During the Communist regime, the historical significance of the place was expressed by reusing the ancient name of Napoca, in addition to its medieval name of Cluj (through the State Decree no. 194 from $16^{\text {th }}$ October 1974, for political and ideological reasons, as expressed by the following objectives: In order to eternalize the name of this ancient settlement - as a testimony of the age and continuity of the Romanian people on these lands).

Even though the ancient name of Napoca has long been lost, proven by the appearance of the new name Clus, at the moment of its re-establishment soon after the Mongol invasions in 1241 , the ruins, partially covered by sediments, were preserved and were a ready to hand source of building materials for the first fortified enclosure of the settlement, allowing a particular preservation of the local history (Pascu, 1975, p. 80). The Roman ruins are still visible today under covered sites in the Union and Museum Squares and also in the foundations and walls of several very old buildings, such as the Franciscan Church (Pascu, 1975, p. 41).

The Middle Ages endows the city with a second, even stronger, fortification system and privileges within the limited intramuros space, besides the emergence of the first stone masonry structures with one-storey above the ground floor or semi-basement. Gradually, the Gothic prevails to the detriment of the Roman architecture, as it can be traced in the adjusted structures of the churches specific to this period. Shortly thereafter several scientific, cultural, social, and religious reforms and developments specific to the Transylvanian Renaissance outlined its today's dynamic urban look.

\section{STATE OF THE ART}

The city centre has a strategic position within the urban system. The city centre morphological features and values are genuinely emblematic markers both for the city history and development and for its inhabitants. The significance of this area is given by its ascribed historic, functional, landscape, and symbolic features. One of the classical patterns through which the city centre is spatially materialised emerges from meddling open public spaces (especially squares) with monuments and bench-mark buildings. A special case is that of the historic city centres that, as inherited areas, continue to have a major role in the structure and functionality of the present urban system due to their users' subjective perceptions (Mishu et al., 2014; Vâlceanu et al., 2014). The functions of the urban public space are in close connection to the particularities of spatial organisation and to their own public spaces' quality.

Recently, within this context, public space has become an intensely debated topic among specialists (Pailliart, 2002; Agachi, 2009; Narciso, 2009; Cullen, 2010; Lynch, 2011; Gehl \& Svarre, 2015), aiming at guaranteeing the attractiveness, sustainability, and economic competitiveness of the urban space (Saradj, 2016). The public space analysis, including its buildings and the way in which connections are settled down between the users and this type of space, represent a significant element in understanding public space functionality. The present urban chaos, car speed and the modern cities accelerated urban life, together with street insecurity, creating sometimes a new urban environment, little favourable to community life in public spaces. Moreover, the unbalance between the system's "included" 
and "excluded" reflects its low and often inadequate use in the urban spatial structure - where the existence of public spaces is less important (Giroto, 2014, p. 4).

In addition, there are several studies that focus on the restructuring and reorientation of the production of goods and services that support a remodelling of space at the urban level, on what has been recently labelled as 'technoscientific urbanism': "Contemporary discussions on 'smart cities' represent an important parallel strand of technoscientific urbanism, in which information technology corporations are aggressively marketing new modes of spatial monitoring" (Brenner \& Schmid, 2015, p. 156). At a functional, spatial, and social level, this phenomenon determines both morphological (re-spatialization, re-drawing of the fabric), functional (reorganization of flow movements, new functional poles) and behavioural consequences (new urban identities, sociological aspects, etc.).

Finally, assessing the central space morphology helps urban designers be more aware of the local development patterns which determine induced transformations upon the traditional urban space (Carmona et al., 2003, p. 61). What we focus on in this paper is related to recently used public space in Cluj-Napoca, since the emergence of certain bank headquarters or McDonald's type multinational corporations. Thus, a balance must be preserved between the dynamic and static approach of these spaces.

\section{METHODOLOGY}

\section{Research methods}

The dimensions by which culture manifests itself are material, mental, and social, while culture differentiates both from the humans' universal nature (i.e. features characteristic of all humans) and from their individual personality. Culture is both an individual and social construction. People learn by culture, they do not inherit it. That is why culture influences the biological and psychological processes, each individual's behaviour being influenced by the culture he or she grew in with the culture constantly changing (Spencer-Oatey, 2012, pp. 6-7). This theoretical statement is directly and strongly related to our research methodology in collecting and analysing research data and to our approach to analysing and discussing inhabitants' perceptions of the central squares and life quality in Cluj-Napoca.

Besides the relevant studies of rich national and international literature selected in the abovementioned theoretical background, the present research started from two theses written by two of the authors of this paper (Adorean, 2016; Maroşi, 2015). Previous research on the cultural landscapes of Cluj-Napoca squares was equally useful (Dulamă et al., 2016). The earliest research (among the above-mentioned ones) regarding the built heritage of ClujNapoca, was the thesis on Cultural Landscapes in the Historical Centre of Cluj-Napoca (Maroși, 2015), which included a selection of relevant information for urban planning from the rich local history, many translations of original manuscripts and more than 200 architectural drawings of the facades of three quarters of the intra-muros buildings. This ample research followed the principles of Historical and Archaeological Studies (as those used in correlation with the General Urban Plan), but all these from a holistic-geographical perspective, making this thesis a document from which several other specific research papers have taken roots. Regarding only the oldest urban core and its cultural landscape (Museum Square), a study appeared (Dulamă et al., 2016), but this time based on a didactic perspective, demonstrating how and why studying the local landscape and history can improve the inhabitants' perceptions of the 
public spaces and therefore influence bottom-up decision making in urban planning (public consultations, maintenance of private historical buildings and also raising awareness and developing respect for the local history, which, in many cases, proved to be the genesis of very unsuccessful projects).

The second thesis, Urban Design and the Functionality of the Public Space in the Municipality of Cluj-Napoca (Adorean, 2016) relied more on the functional aspects of the city than on its structures and aesthetics, successfully covering all the aspects which were not among the objectives of the first thesis, including a vast accounting of the central squares urban furniture, a detailed assessment of the functional zones and surfaces of the squares, a valuable survey about inhabitants' perceptions of the central squares and quality of life in Cluj-Napoca, and a relevant comparison of the resulted information with the European literature and published statistics.

For data collection on peoples' perceptions of the central squares and life quality in ClujNapoca, we conducted a questionnaire survey and thus administered 300 face-to-face questionnaires on the investigated public squares in March and May 2016.

The second method was based on direct (in loco) observation, thus obtaining useful information about the area of study, its users, but also about the functionality or type of generated inter-human relations. The third method consisted of thematic photography of the objects, objectives and malfunctions manifested in the studied area. Lastly, the latter two processes were based on cartographic mapping of the territory, namely the inventory of existing facilities in those six urban public squares.

The questionnaire was structured in two sections: the user's profile, respectively the perception and user experience of the squares. The user's profile (the first nine questions, of which three open ones) gathered important data about the characteristics of those visiting the squares, which were then correlated with their perception of the used / visited public space (of the other 13 questions of the questionnaire, five were open, two half-open, while seven were closed, respectively). The days when the questionnaires were administered were randomly chosen (the only restrictive factor was the weather conditions), summing up a total of 12 different days.

\section{Participants}

The sample size of the respondents was 300,50 for each of the six squares in the case study, of which the target group was all users of those squares with a minimum age of 15 . The sample had the following features: $52.33 \%$ were women and $47.67 \%$ men, $25.33 \%$ of the users were $15-25$ years old, $23.33 \%$ were aged $25-35$ years old, $14.33 \%$ were $35-45$ years old, $12.66 \%$ were aged 45 to 55 years old, $15.66 \%$ were 55 to 65 years old, and $8.66 \%$ were over 65 years old. Those who completed their university studies represented $38 \%$ of the respondents and those who graduated high school accounted for $37 \%$. Additionally, the persons who completed postgraduate studies (Master's or Ph.D.) accounted for $12 \%$ of the total number of questionnaires, while the others graduated the primary school and gymnasium.

The active population of the sample accounted for $70 \%$ of the total. The activity structure of the active population highlighted a prevalence of the tertiary sector (services, constructions and transport) $-66.19 \%, 10.95 \%$ active in the quaternary sector (scientific research and innovation), while the first two activity sectors were less frequent, thus the secondary sector covered $2.66 \%$, and the first one only $0.33 \%$, the remaining $18.57 \%$ being retired. The inactive population, representing $30 \%$ of the 300 surveyed people included the unemployed, housewives, students, and pupils.

The users' ethnic structure revealed a predominance of the Romanian nationality (82.66\%), 
Hungarian (12.33\%), followed by Ukrainian 1.33\%, Albanian, British, Croatian, French, Greek, Italian, Dutch, Portuguese, Syrian, Tunisian, and Turkish (one person for each nationality).

Moreover, the users' profile emphasizes that this city has a centripetal nature, while, at the same time, the ethnic, social, cultural, or behavioural heterogeneity is stressed. Hence, the distribution by residence showed that $34 \%$ of the respondents were living outside, while the other $66 \%$ within the city.

\section{Research material}

In this paper, as stated before, we used the results from the 2016 survey. Besides this, we also used data from the extensive field research achieved through direct observation, inventories, and photographs.

A database was created in the Microsoft Office Excel programme with the answers to the questionnaire, processing these data afterwards. In addition, the photographic material was selected and analyzed. The analysis based on geographic-information methods was the penultimate stage of this paper, defined by the multicriterial urban planning analysis, quantitative data processing and thematic maps using specialized software, namely ArcGis, Global Mapper, Google Street View, and Google Earth.

Having the urban diagnosis as a starting point, we aimed at presenting a general view of the functionality and design of Cluj-Napoca central public squares (i.e. Avram lancu, Lucian Blaga, Mihai Viteazul, Museum, Ștefan cel Mare, and Union), through their users' eyes, and by means of the above-mentioned methods.

\section{RESULTS AND DISCUSSION}

This part of the paper is structured according to several topics. Firstly, we summarized the present central urban configuration of Cluj-Napoca, secondly, based on an extensive field research we presented the features and functions of the central squares of this city (Union Sq., Museum Sq., Mihai Viteazul Sq., Avram lancu Sq., Ștefan cel Mare Sq., and Lucian Blaga Sq.), thirdly, we listed and discussed on the questionnaire results background, the respondents' perceptions of Cluj-Napoca central squares and quality of life, focusing on the functions of these squares and on the main factors which were influencing people to use the available spaces, and, fourthly, we discussed the matter of experiencing the cultural landscapes of the urban public space in Cluj-Napoca. Finally, taking all these into account, after identifying a series of dysfunctions, we proposed actions which could reduce or eliminate them in a prior order. Considering this, many in detailed territorial inadvertences may require special dedicated research, and therefore, throughout this paper, we will include future subjects to be analized for a better coverage of the problems and a more efficient production of solutions.

\section{Nowadays' central urban configuration of Cluj-Napoca}

Cluj-Napoca historic centre has a strong cultural identity due to its unique built heritage (mixed and unique architecture). Its central public spaces are reflecting these features at best. The public spaces of Cluj-Napoca city centre are defined by all the streets, green spaces and historic public squares (as they emerged: Museum Square on the north-western side of the historic centre, Union Square in the middle, Avram lancu Square on the east, Ștefan cel Mare Square on the south-east, Lucian Blaga Square on the south-west, and Mihai Viteazul Square 
on the north side) (Fig. 1). The city centre rectangular network of streets confers a special look to the urban blocks. However, to understand Cluj-Napoca city centre development, we introduced and discussed the urbanistic impact of its social, economic, and cultural development in a previous study of ours (Maroşi et al., 2019).

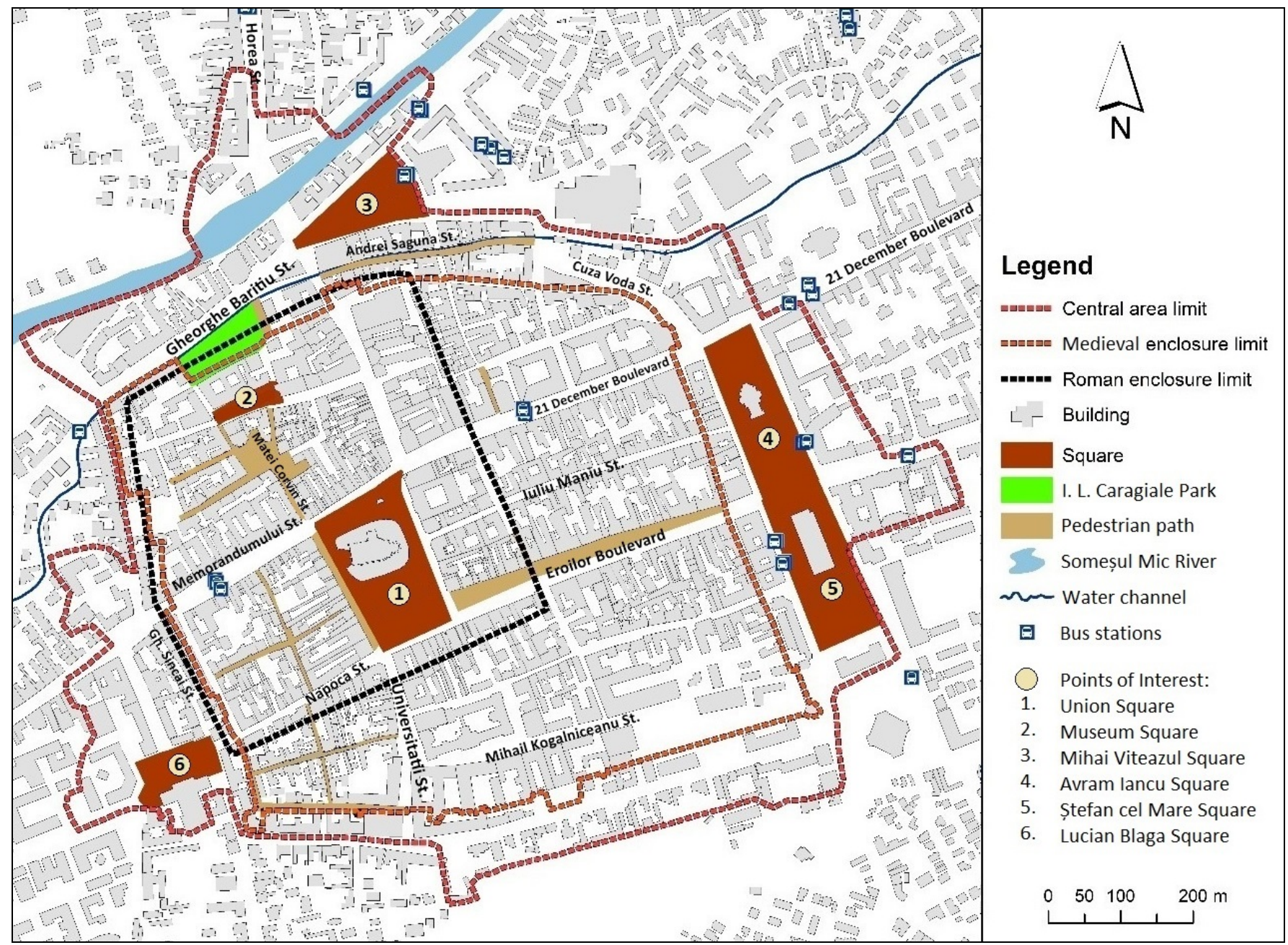

Figure 1: Setting out Cluj-Napoca central area and its squares

The establishment of pedestrian zones started between 2006 and 2007 with the Museum Square and Heroes' Boulevard. Having a centripet character, the initiative of the pedestrian area of Cluj-Napoca aimed to provide better and enjoyable walks, to reduce pollution, traffic and accidents, and to hold on to business.

Currently, on the one hand, Cluj-Napoca has about $60,596 \mathrm{~m}^{2}$ of pedestrian and semipedestrian areas (areas without or with conditioned traffic), all located in the central area of the city (Fig. 2). These areas are, however, discontinuous. Five of the six historical squares (except for Lucian Blaga Square) can be considered as pedestrian areas (Museum Square), respectively semi-pedestrian (the other four). Union Square is the largest, with its pedestrian area exceeding $12,000 \mathrm{~m}^{2}$, while the total (at the same time pedestrianized) area of the Museum Square (the smallest of the squares) reaches $2,554.55 \mathrm{~m}^{2}$. On the other hand, the city centre also includes 14 pedestrianized and / or semi-pedestrianized streets. The largest of 
these with regard to the pedestrianized area is Heroes' Boulevard $\left(7,682 \mathrm{~m}^{2}\right)$, followed by Andrei Şaguna Street $\left(1,974 \mathrm{~m}^{2}\right)$, Potaissa Street $\left(1,835 \mathrm{~m}^{2}\right)$, Inocențiu Micu Klein Street $(1,258$ $\left.\mathrm{m}^{2}\right)$, Ioan Bob Street $\left(1,222 \mathrm{~m}^{2}\right)$, Matei Corvin Street $\left(1,038 \mathrm{~m}^{2}\right)$, etc.

It is significant to mention that cycling tracks are connecting these public squares and enable communication with and within the city centre (Fig. 2). At the end of 2015, Cluj-Napoca had about 10 cycling tracks mainly located in the city centre (21 December 1989 Blvd., Heroes Blvd., Dorobanţi Street, Horea Street, Piaţa Unirii Street, Possada Street, and University Street) and along Someşul Mic River. Their length does not exceed $7 \mathrm{~km}$ (the second place after Bucharest at the national level regarding the number of cyclists), which does not lead to a real urban cycling network (Bolog \& Mathe, 2015, p. 85).
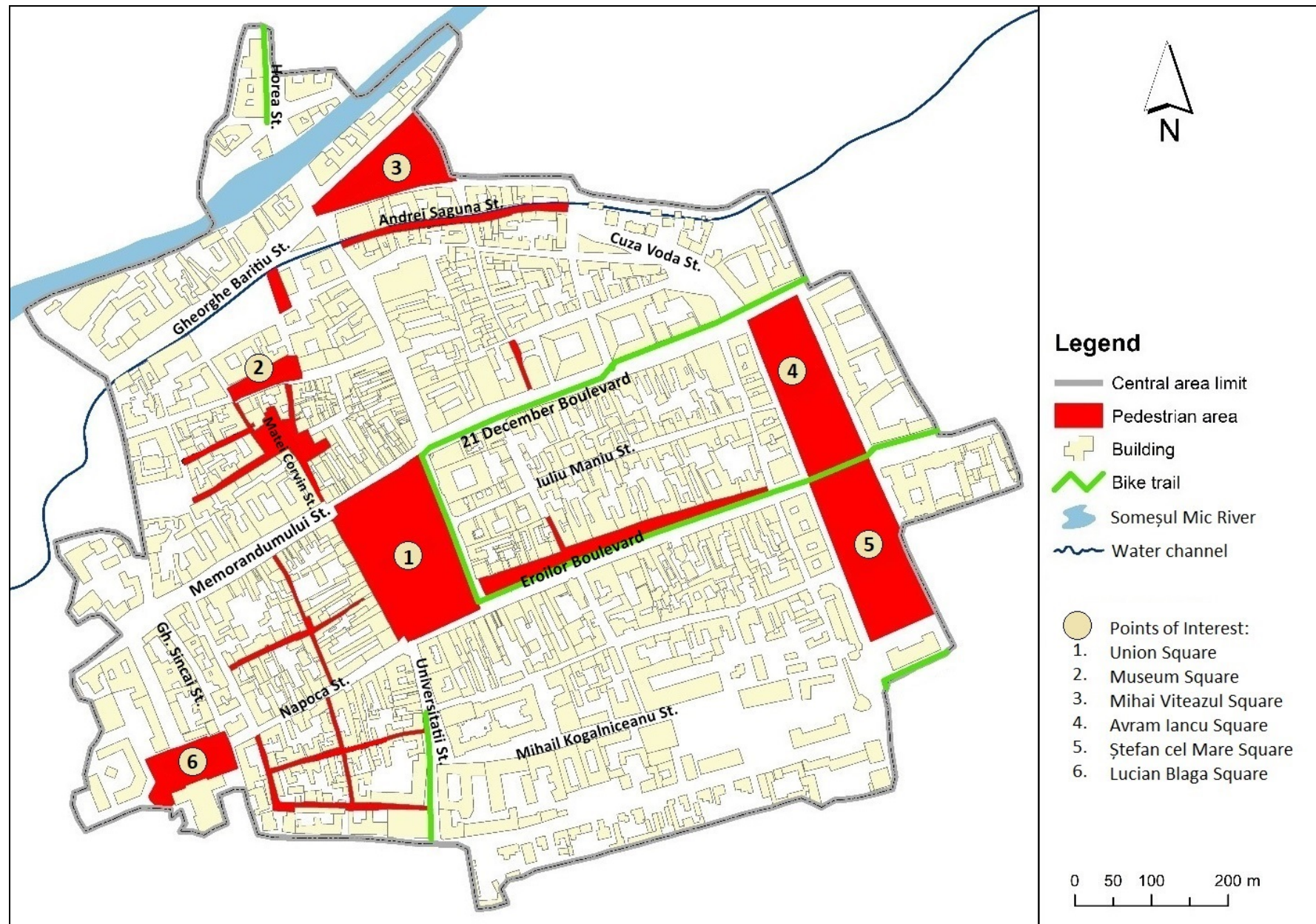

Figure 2: Cycle paths and pedestrian / semi-pedestrian areas in the central area Cartography: Emanuel-Cristian ADOREAN, 2019

The height of buildings in the city centre is another urban index that defines the attempt to unify the interference between the architecture and the design of this public space. Most of the buildings in the city centre (70.75\%) are low-rise, which largely corresponds to the current urban planning provisions and building restrictions or maximum allowed heights code regulations for this area. Two- or three-storey buildings, with at least a loft, have a share of $26.19 \%$ of all buildings in the city centre (Fig. 3 ). 


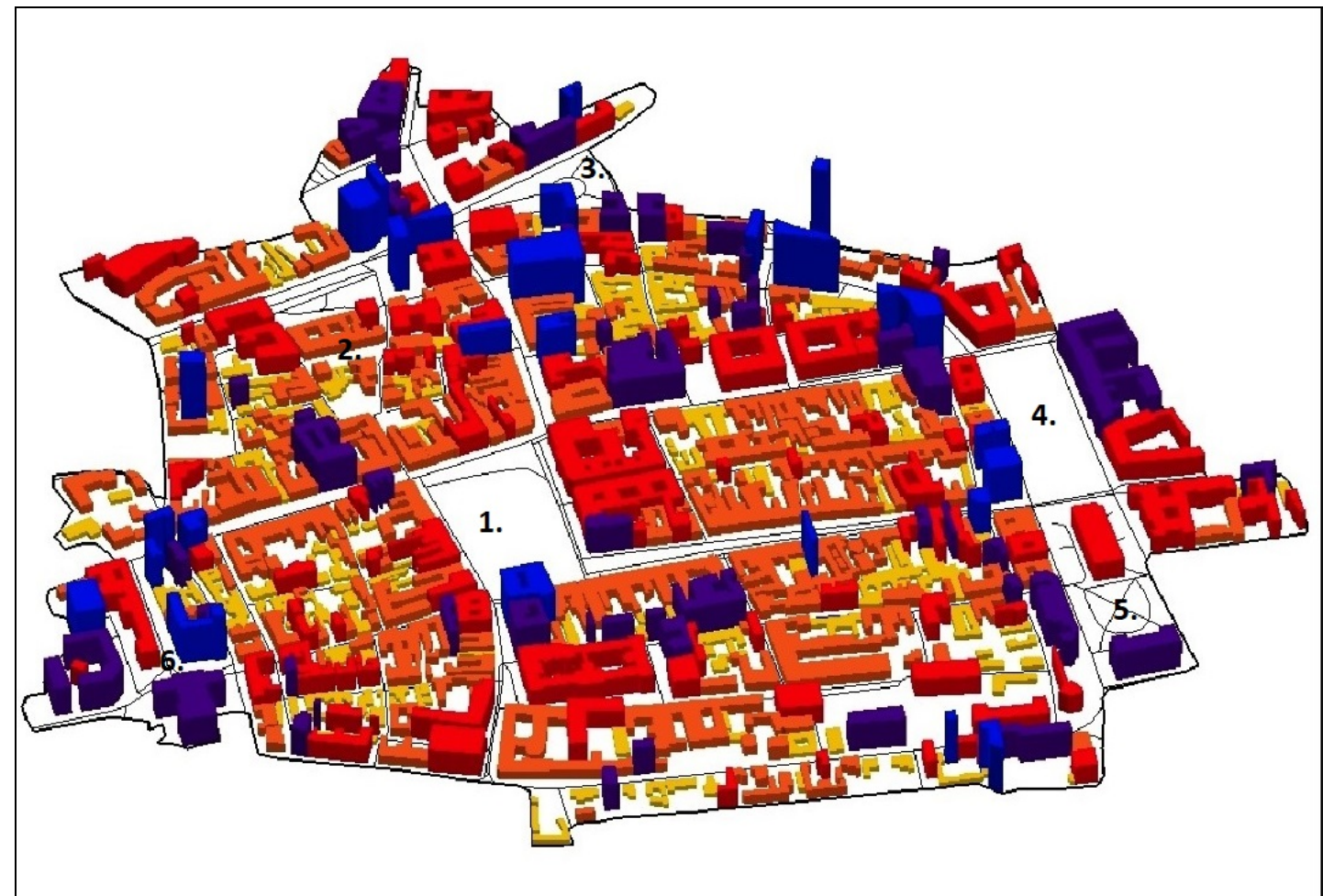

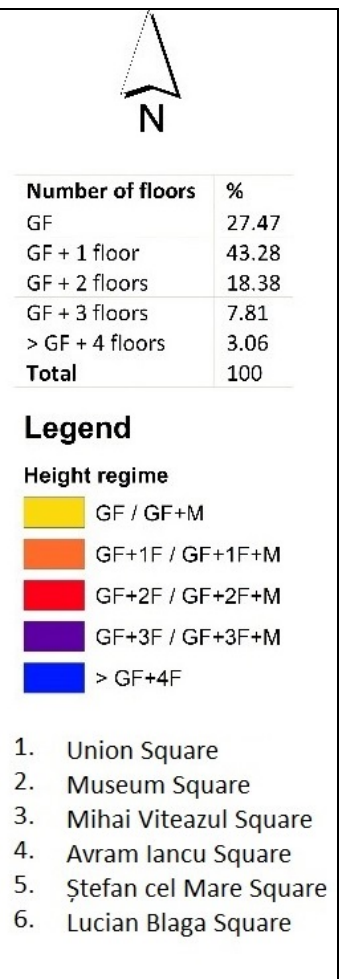

Figure 3: Three-dimensional perspective of the current height regime of buildings in the central area Cartography: Emanuel-Cristian ADOREAN, 2019

The central squares of Cluj-Napoca. Present features and functions

The specific objectives set up at the earliest stage of the study suppose the territorial diagnosis of the squares in the study area (Avram lancu Sq., Lucian Blaga Sq., Mihai Viteazul Sq., Museum Sq., Ştefan cel Mare Sq. and Union Sq., respectively), the degree of functionality analysis of the urban elements that integrate into the structure of the investigated space, their current role in the view of the users based on their perception and experience regarding the public space, as well as the aesthetic evaluation of the cultural landscapes characteristic of the squares in the central area of Cluj-Napoca.

\section{Union Square}

Union Square is the largest, with its pedestrian area exceeding $17,000 \mathrm{~m}^{2}$, while the total (at the same time pedestrianized) area of the Museum Square (the smallest) reaches $2,527 \mathrm{~m}^{2}$ (Table 1). The aristocratic look of the square, despite some attempts to remove it during the Communist regime, has remained deeply embedded, currently providing the most significant cultural identity of the city. Despite the local authorities' efforts, the share dedicated to vehicles, including parking spaces, occupies a significant area $-6,288 \mathrm{~m}^{2}(20 \%)$. Green areas extend up to $4,256 \mathrm{~m}^{2}(13 \%)$, while other surfaces up to $14 \%$, such as the fountain $\left(314.84 \mathrm{~m}^{2}\right)$, the archaeological site (roughly $82 \mathrm{~m}^{2}$ ), and the Statue of Matthias Corvinus, located in its centre (Fig. 4).

The existence of street furniture illustrates the result of the efforts by local specialists to make this square the main stage for community events in Cluj-Napoca. Thus, the square has a relatively high number of benches (42 pieces), cubes for sitting (9 pieces) near the fountain, 28 trash bins, 15 urban flower pots, 3 flag posts, 3 information panels, one public toilet, and a bicycle stand. The external sidewalks have scattered located trees. 


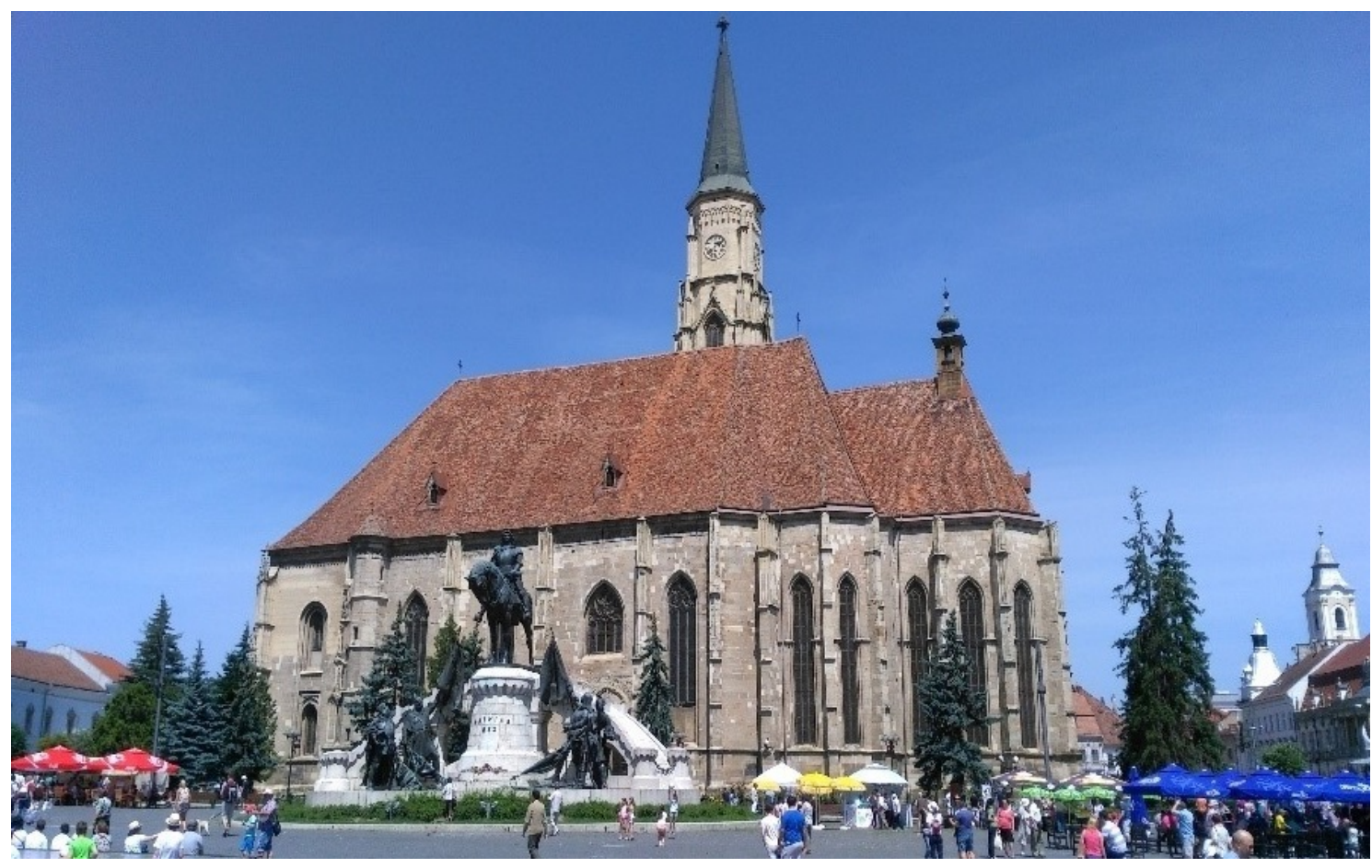

Figure 4: Landscape of Union Square: mirroring the history of Cluj-Napoca

Source: Emanuel-Cristian ADOREAN, 2016৫

Table 1: Territorial balance of the squares from Cluj-Napoca city centre (Maroși et al., 2019)

\begin{tabular}{|c|c|c|c|c|c|c|c|c|c|}
\hline \multirow[t]{2}{*}{ CENTRAL SQUARES } & \multirow{2}{*}{$\begin{array}{c}\begin{array}{c}\text { Total } \\
\text { surface* }\end{array} \\
\mathrm{m}^{2} \\
\end{array}$} & \multicolumn{2}{|c|}{$\begin{array}{l}\text { Pedestrian } \\
\text { surface }\end{array}$} & \multicolumn{2}{|c|}{$\begin{array}{l}\text { Road } \\
\text { surface }\end{array}$} & \multicolumn{2}{|c|}{$\begin{array}{c}\text { Green } \\
\text { area } \\
\text { surface }\end{array}$} & \multirow{2}{*}{ 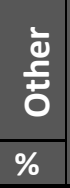 } & \multirow[t]{2}{*}{ Functions } \\
\hline & & $\mathrm{m}^{2}$ & $\%$ & $\mathrm{~m}^{2}$ & $\%$ & $\mathrm{~m}^{2}$ & $\%$ & & \\
\hline Union Sq. & 32,000 & 17,000 & 53 & 6,288 & 20 & 4,256 & 13 & 14 & cultural, tourist \\
\hline Museum Sq. & 2,880 & 2,527 & 88 & 128 & 4 & 133 & 5 & 3 & Tourist \\
\hline Mihai Viteazul Sq. & 13,400 & 2,680 & 20 & 5,226 & 39 & 2,144 & 16 & 3 & $\begin{array}{c}\text { commercial } \\
\text { transit }\end{array}$ \\
\hline Avram lancu Sq. & 24,110 & 4,822 & 20 & 9,991 & 41 & 7,544 & 31 & 7 & $\begin{array}{c}\text { administrative } \\
\text { religious }\end{array}$ \\
\hline Ştefan cel Mare Sq. & 29,800 & 9,230 & 31 & 8,640 & 29 & 8,340 & 28 & 12 & $\begin{array}{c}\text { cultural } \\
\text { recreational }\end{array}$ \\
\hline Lucian Blaga Sq. & 5,900 & 2,360 & 40 & 3,068 & 52 & 413 & 7 & 1 & $\begin{array}{l}\text { educational } \\
\text { transit }\end{array}$ \\
\hline
\end{tabular}

The most important functions of the buildings located in this square are cultural (Cluj-Napoca Municipal House of Culture), touristic (due to the presence of Matei Corvin's statue near the cathedral) and recreational (two hotels, several pubs, a series of fast food units and a large number of restaurants and coffee shops), as well as religious (e.g. St. Michael's Cathedral), administrative (National Bank of Romania and Centre for Crime Prevention), social (the public space itself, but also the recreational buildings already mentioned), educational (Universității Bookstore, University of Arts and Design), and commercial (pharmacies, shoe and clothing 
stores, etc.). As a consequence, users opt for recreational activities (walking, reading, smoking, listening to music, dancing, resting), attending shows, attending religious services, meeting friends and family members, walking around the children or purchasing souvenirs or specific products when fairs are organized.

\section{Museum Square}

The total surface area of the square amounts to approximately $2,880 \mathrm{~m}^{2}$, with a pedestrian area of $2,527 \mathrm{~m}^{2}(88 \%)$, road surface, represented by Constantin Daicoviciu Street on the eastern side of the square, with only $128 \mathrm{~m}^{2}(4 \%)$, while green areas account for $133 \mathrm{~m}^{2}(5 \%)$. Other categories (3\%) include Carolina Obelisk (1.2\%). The street furniture was adapted to the size and characteristics of the square, with 11 benches, 6 trash bins, 3 urban flower pots, and one bicycle stand.

The buildings outlining the square have their main functions related to the city's nightlife (a series of clubs and pubs), retail establishments (especially during events - Christmas, Easter, International Women's Day, etc.), food (fast foods and restaurants), followed by recreational (the square with its urban furniture), cultural (Carolina Obelisk Statue), educational (National Museum for the History of Transylvania, where researchers and students carry out scientific activities), and religious activities (The Franciscan Church frequented mainly by Hungarians and tourists).

Compared to other squares from the city centre, the activities, characteristic of this public space are temporary or seasonal. Thus, the most favourable seasons are summer, autumn, and spring. The main activities are touristic, recreational (including nightlife), religious, restoration, educational, retail, and social. On the contrary, in winter, the activities carried out here are considerably reduced, especially those of restoration, social or tourism-related.
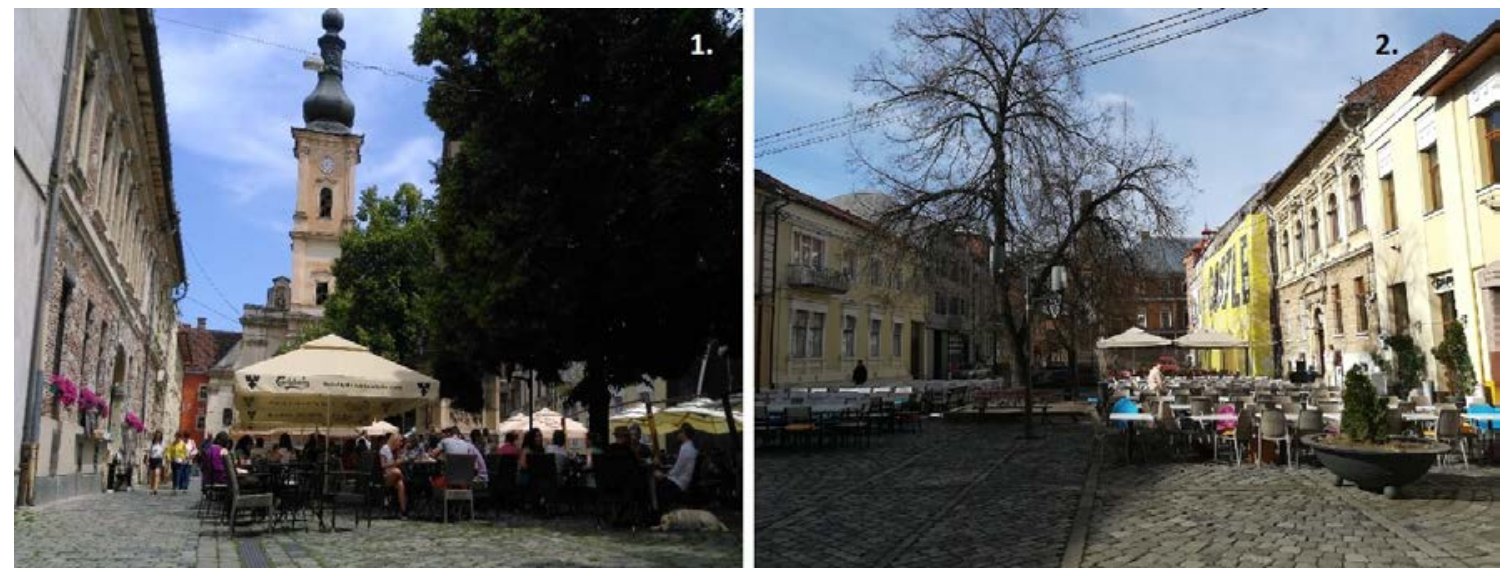

Figure 5: Recreational activities in Museum Square. View: 1. towards east, 2. towards west Source: 1 - Emanuel-Cristian ADOREAN, 2016@ and 2 - Alexandru-Sabin NICULA, 2019@

\section{Mihai Viteazul Square}

In contrast to other squares, Mihai Viteazul Square has fewer symbolic structures. The pavement made of rock slabs is highly degraded and has extensive subsidence. From a total surface area of $13,400 \mathrm{~m}^{2}$, roughly $20 \%$ is pedestrian, and $39 \%$ is dedicated to vehicles. The green areas are spread over the square, on a surface of $16 \%\left(2,144 \mathrm{~m}^{2}\right)$. Other space categories comprise the fountain with 1.2\%, and two monuments (Fig. 6): "The Eternal Flame" (dedicated to the memory of Mihai Viteazul and his soldiers) and Mihai Viteazul Statue, with 1.8\% (Table 1). 


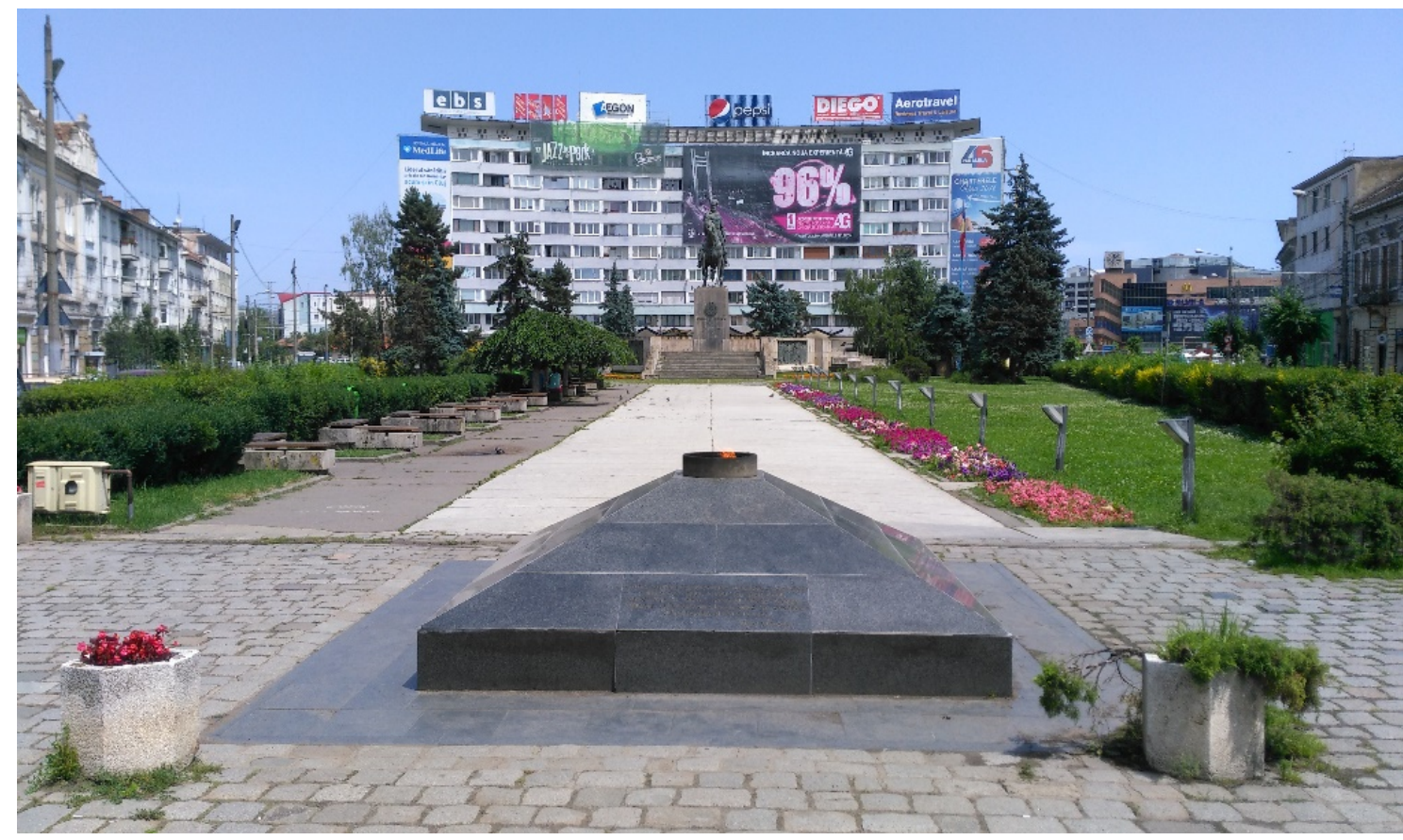

Figure 6: Mihai Viteazul Square - view from the west

The historic photographs of the interwar period exhibited by the city hall in various places of the historic centre, mainly in the windows of unused commercial spaces, emphasize a flourishing period that is also reflected in the buildings which had become richly ornamented, with ground floors adjusted to various commercial functions.

Street furniture is represented by the insertion of benches ( 29 pieces) and 18 trash bins. The two ticket stands and the automatic ticketing machine for the urban public transport system emphasize the transit and transport functions of the square, while the only flag pole is located on a green area. There are also small flower pots ( 20 pieces). The buildings are terraced, the land occupation percentage recording extremely high values.

The characteristic activities are commercial, cultural and recreational (e.g. due to the presence of "Florin Piersic" Cinema). Other activities include walking children and pets, photography, feeding pigeons, social meetings, alcohol consumption, transit, and waiting for public transportation.

\section{Avram lancu Square}

As a symbol of Romanianism, Avram lancu Square (Fig. 7) was designed as an ornamental square during the $19^{\text {th }}$ century, later becoming a new civic centre (A.N.T / N.A.T., 2015, p. 24). There is a large number of buildings with religious, administrative and juridical functions, such as the Protestant Theological Institute, the Orthodox Metropolitan Cathedral, the Palace of Vad, Feleac and Cluj Archdiocese, Cluj Railway Regional Institute, the Palace of Finance, the Regional General Directorate of Finance, the Prosecutor's Office of Cluj-Napoca Law Court, "Lucian Blaga" National Theatre and the Palace of the Prefecture of Cluj County, respectively comprising this area. Surrounded by a musical fountain, Avram lancu statue is located on the central-southern side of the square, while the Unknown Soldier's Monument is lodged on the northern side. 
Of that $24,110 \mathrm{~m}^{2}$ total area, the green space is prevalent, $31 \%\left(7,544 \mathrm{~m}^{2}\right)$ of the surface being covered by vegetation. The outside / external road sides of the square represent $41 \%$, of which $6 \%$ are parking areas. Having a recently built pavement, the pedestrian side of the square covers $20 \%\left(4,822 \mathrm{~m}^{2}\right)$, although the area of the cathedral building $(4 \%)$ falls into other surfaces category, with a total percentage of $7 \%$ (see Table 1 ).
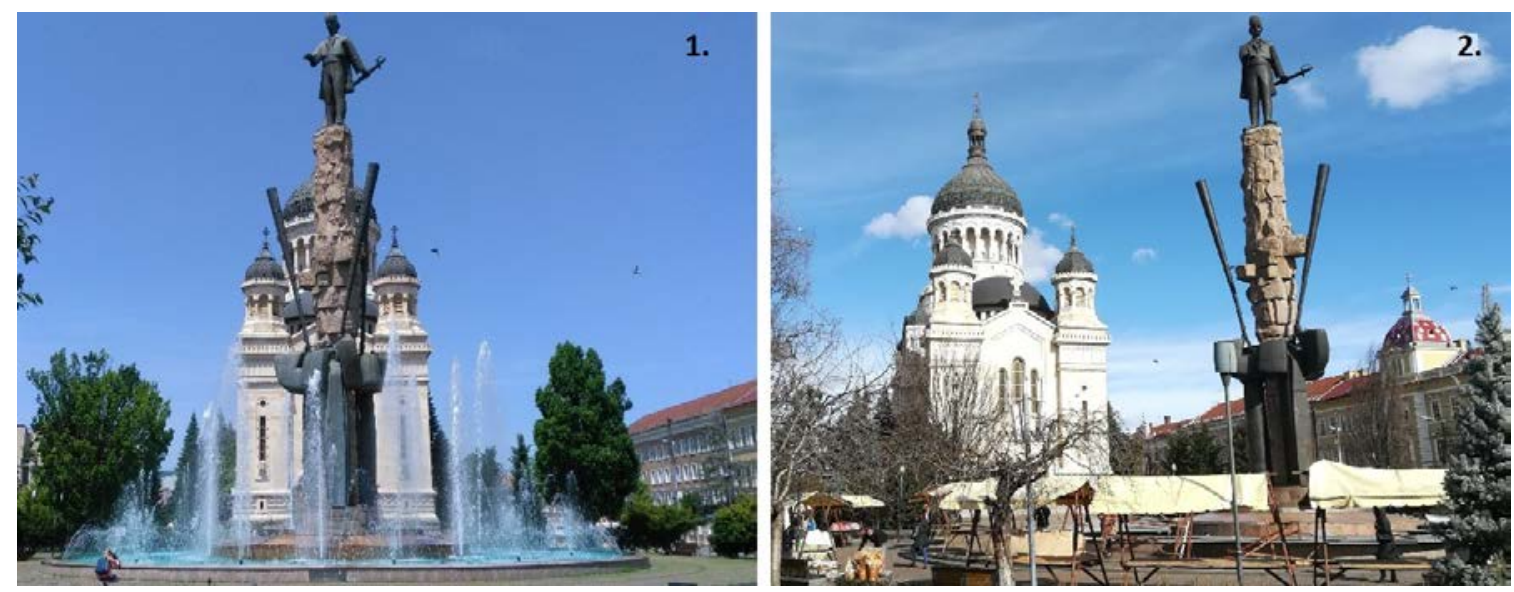

Figure 7: Avram lancu Square - interior view from the south

Source: 1 - Emanuel-Cristian ADOREAN, 2016C and 2 - Alexandru-Sabin NICULA, 2019C

The urban furniture, characterized by almost perfect symmetry, is composed by a considerable number of benches (26 pieces), 22 street trash bins, 22 Romanian flags - eleven on the left side and another eleven on the right side - and five informative panels.

\section{Ștefan cel Mare Square}

Neighbouring Avram lancu Square, Ștefan cel Mare Square (Fig. 8) is dominated by "Lucian Blaga" National Theatre and The Romanian Opera, built between 1904 and 1906 (Fig. 9). Outside, on the eastern side, the Palace of Justice and the Command of the Fourth Army of Transylvania rise, while the Tailor's Tower and a part of the medieval fortress wall that delimited the city during the $15^{\text {th }}$ century is placed on the western side (A.N.T / N.A.T., 2015, p. 24).
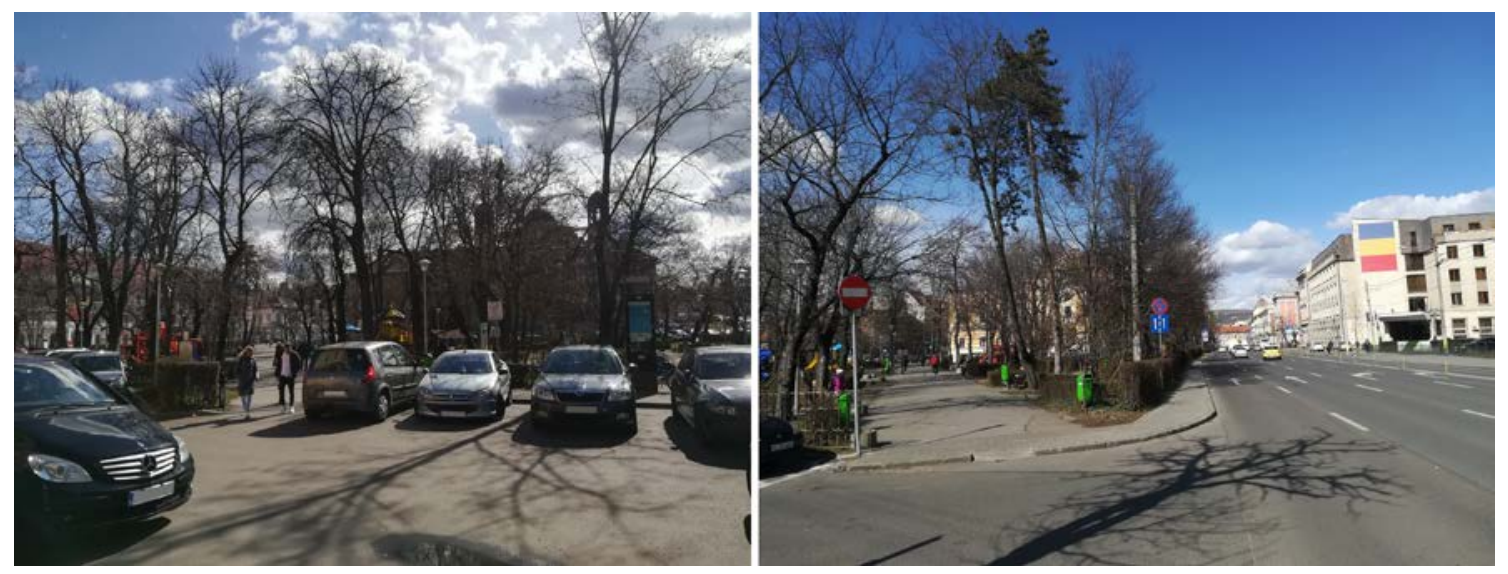

Figure 8: Ștefan cel Mare Square

Source: Alexandru-Sabin NICULA, 2019๔ 

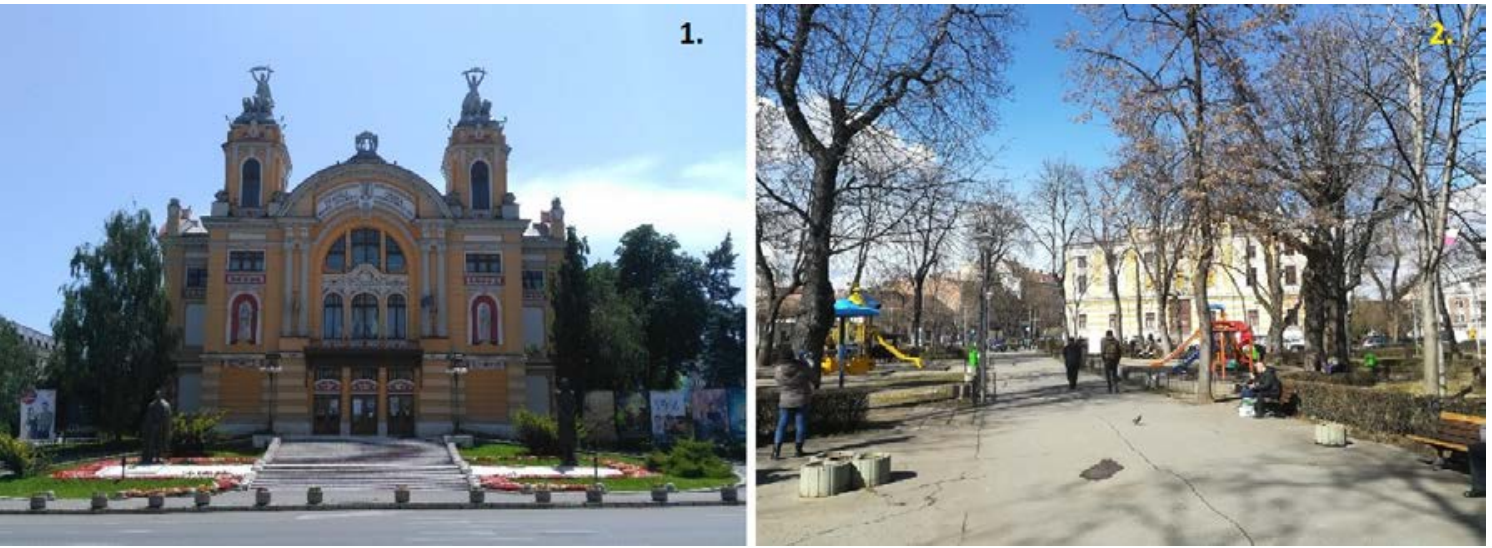

Figure 9: "Lucian Blaga" National Theatre and the Romanian Opera. 1 - Front side; 2 - Back side Source: 1 - Emanuel-Cristian ADOREAN, 2016@ and 2 - Alexandru-Sabin NICULA, 2019@

The green area covers $8,340 \mathrm{~m}^{2}(28 \%)$ of the total square surface $\left(29,800 \mathrm{~m}^{2}\right)$, the pedestrian area covers $31 \%$ compared to $29 \%$ of the road sides, the latter one having an exclusive role of serving the National Theatre and Romanian Opera building, which has a percentage of approximately $9 \%$ of the square perimeter (Table 1 ).

The characteristics of this square derive from the interference of its two main functions, i.e. cultural and recreational. The urban furniture is made up of 42 low-quality wooden benches and 42 street trash bins, positioned along the footpaths or near the playgrounds, giving better visibility to this space. The informative panels, excepting the municipality tourist map located on the northwestern side, have the role of warning the passers-by, thus protecting the vegetal species hosted by this area. On the northwestern side, a self-service bicycle rental station is located, whilst in its immediate proximity there is a news stand placed on the pedestrian axis. The street flower boxes, similar to those from Mihai Viteazul Square, are distributed along the pedestrian axes ( 22 tracks), as well as on the northern side, at the crossroad between the road and the sidewalks (26 pieces).

The specific activities are walking and supervising children, relaxing (reading, smoking, contemplation, and telephone conversations), socializing, meeting friends, walking pets, transit, drinking and so on.

\section{Lucian Blaga Square}

Lucian Blaga Square formerly known as the Peace Square is located to the west of the first city nucleus, hosting buildings from the $19^{\text {th }}$ century and mid-20 $0^{\text {th }}$ century (Ciorca, 2012) on its sides. Access to urban areas is enabled by the six arterial roads crossing this square. Two of the symbolic buildings of the city are located here: "Lucian Blaga" Central University Library and the Students' Culture House (Fig. 10). It has cultural, educational and entertainment (characteristic to the Students' Culture House) functions. Close to this square are "Alexandru Borza" Botanical Gardens and Cluj-Napoca City Hall.

The territorial balance shows a very high percentage of arterial roads that divide the square (the roads cover $3,068 \mathrm{~m}^{2}$ out of the total square surface of $5,900 \mathrm{~m}^{2}$, which is $52 \%$ of the total area, of which $3 \%$ are parking lots). However, the pedestrian area covers $40 \%\left(2,360 \mathrm{~m}^{2}\right)$, while the green area covers only $413 \mathrm{~m}^{2}(7 \%)$ (Table 1 ). 
The urban furniture is rather poor, characterized by benches (13 pieces located near the library), some street trash bins (ten pieces), three flags placed in front of the library, two informative panels, two bicycle racks, nine florists' spaces (Fig. 10) specially set up by the Local Council for tradesmen of the city.

The main functions hosted by the buildings around the square are cultural, educational, financial-banking, commercial, and residential. Because in this square the urban tissue is highly fragmented by arterial roads (Fig. 11), the specificity of this square is given by the existence of buildings located apart on the plot.

These are the main activities related to this area: attending shows, indoor library educational activities, work, socializing, transit, shopping, gastronomic activities, and nightlife related ones.
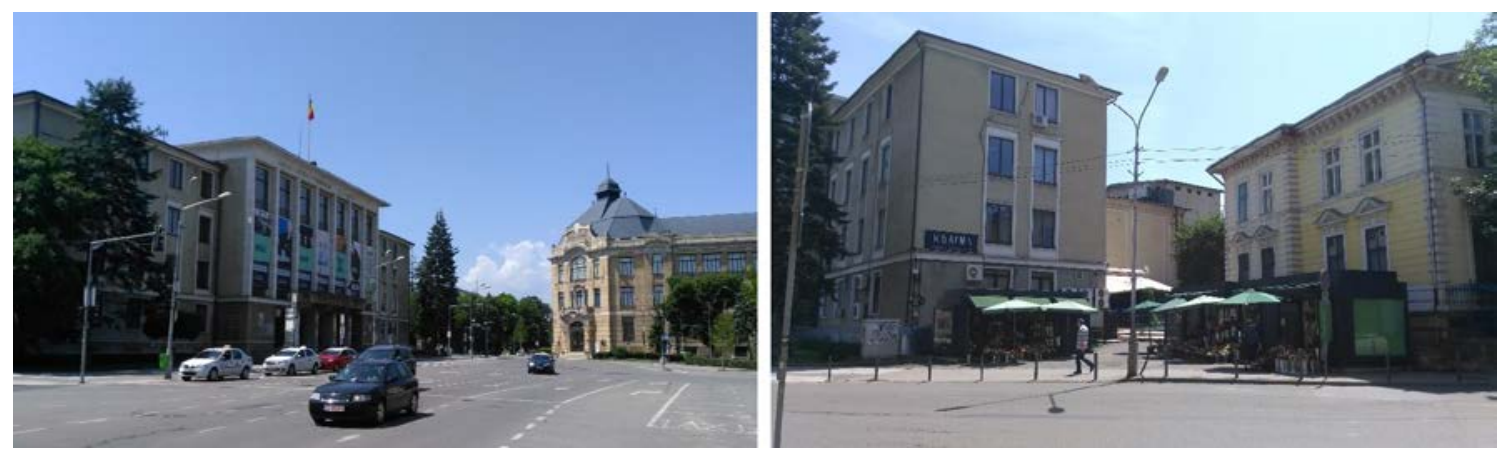

Figure 10: The central part of Lucian Blaga Square. Florists in Lucian Blaga Square Source: Emanuel-Cristian ADOREAN, 2016 (C)
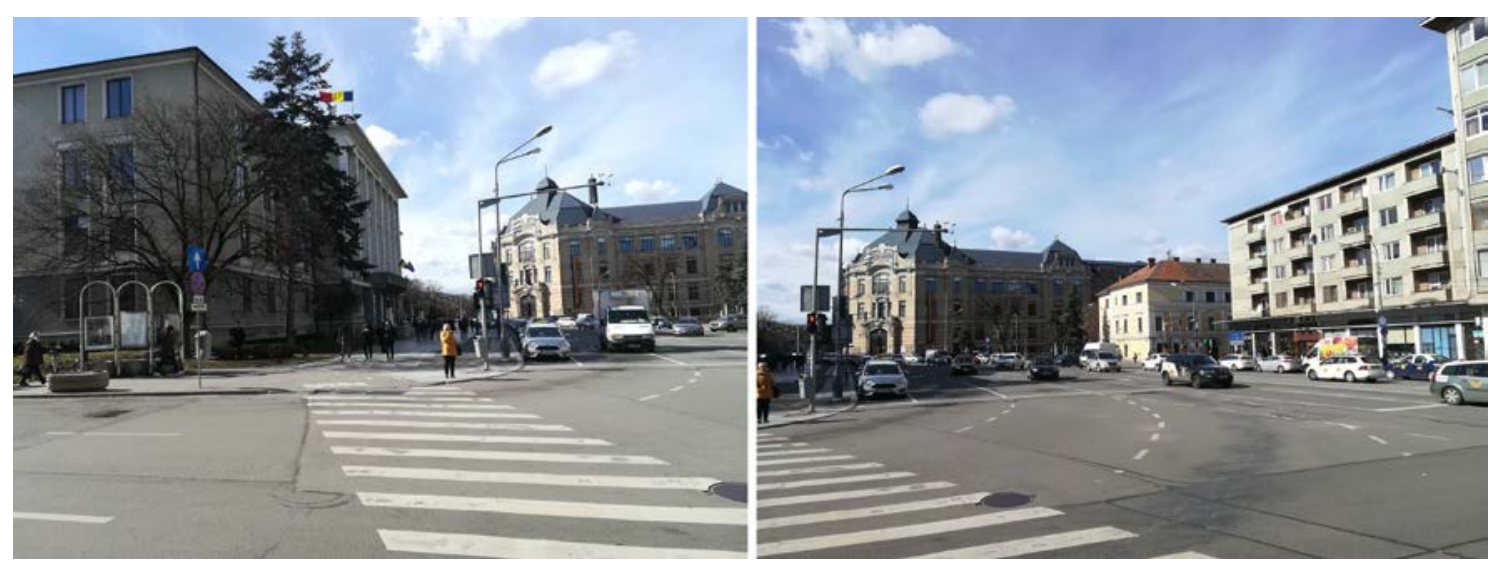

Figure 11: Lucian Blaga Square

Source: Alexandru-Sabin NICULA, 2019@

\section{Cluj-Napoca central squares. Respondents' perceptions and quality of life}

We were able to identify peoples' perceptions of the life quality related to activities performed in central Cluj-Napoca and space quality, as a result of the questionnaire survey that we conducted on 300 people in March and May 2016. 


\section{Main factors determining people to use the squares}

Generally, architects and urbanists consider that one of the strongest urban space issues today is mainly the crisis emerged from unsuccessful attempts to create it and "not only its actual lack in recent urbanised areas support this assertion, but also its stifling, pollution (including the visual one in the old neighbourhoods), organising and more or less permanent occupations" (Moldovan \& Purcar, 2012, p. 7).

Gehl \& Svarre (2015, p. 107) identify 12 criteria for assessing public space quality. These can be included into three specific functional aspects of approaching open urban spaces: citizen's safety (determined by protection against traffic accidents, against crime and violence, and against unpleasant sensorial experiences, able to bear psychologically on the user); providing facilities (potential for walking, parking, sitting, contemplating the landscape, listening and talking, playing and other activities, and for small scale services); generated image (determined by the place visual aspect and design for positive sensitive experiences). As a result, the values ascribed to urban public space fall into three basic categories: environmental, functional, and aesthetic/symbolic (Macedo \& Robba, 2002, qtd. in Viero Crestani \& Barbosa Filho, 2009, pp. 2-3).

For the public squares of Cluj-Napoca central area, we identified a series of criteria that fall in the same above-mentioned basic categories (i.e. environmental, functional, and aesthetic/symbolic). Respondents assessed the public squares according to these criteria, on a 5-point Likert scale. As a result, we could assess the users' satisfaction degree (Fig. 12).

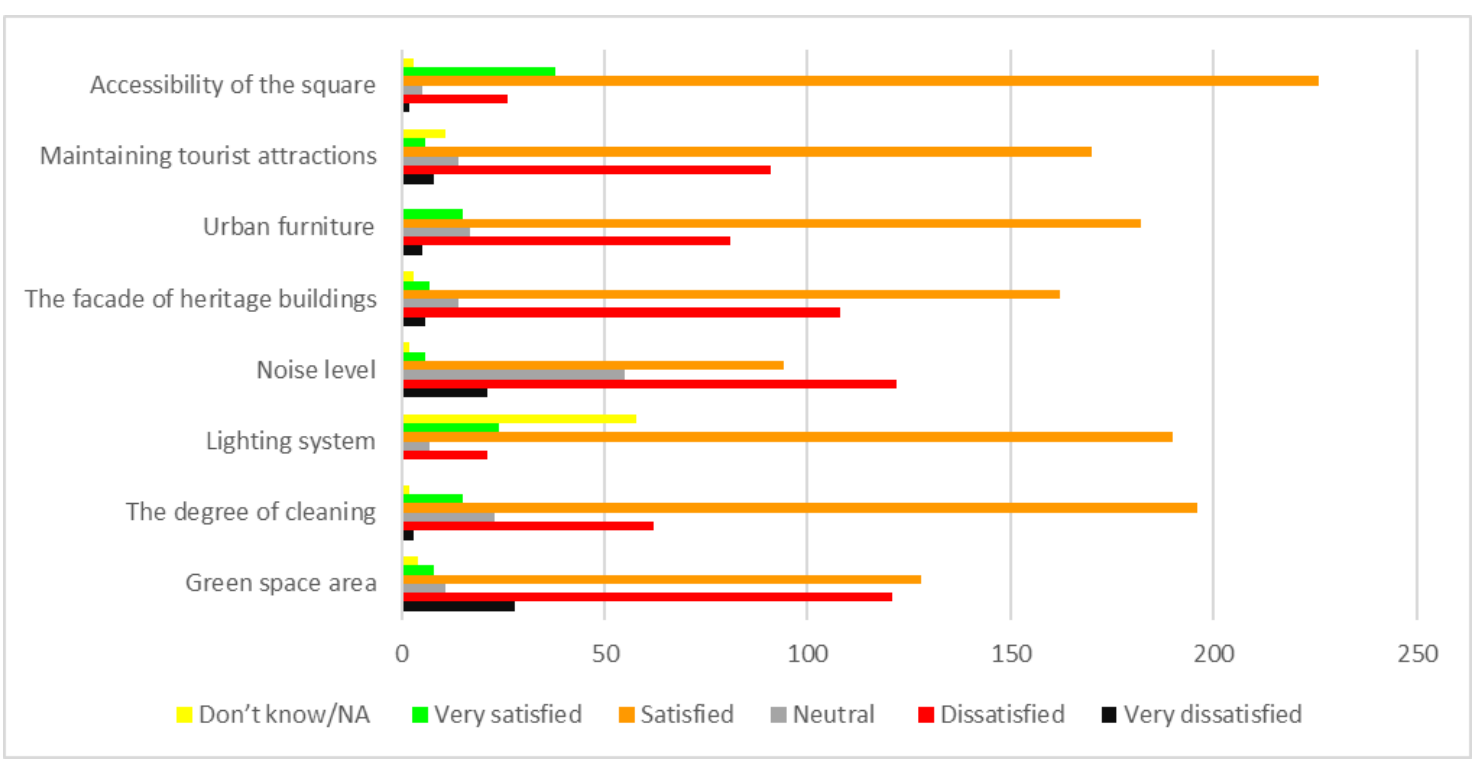

Figure 12: User satisfaction in terms of endowments and functionality of squares

Moreover, related to these basic categories (i.e. environmental, functional, and aesthetic/symbolic), we identified, in case of Cluj-Napoca, the main factors determining people to use the public space and we noticed that these factors differ in significance, depending on the respective square. These factors are linked, in case of Avram Iancu Square, to its central position, its role of connecting different places in the city, its proximity to households, its aesthetic, location of worship places, organised events, tourist and/or historic sites, and to recreational opportunities. 
Lucian Blaga Square is primarily visited due to its location in the close proximity of the prestigious medical units in Transylvania and Romania (Cluj-Napoca Emergency County Hospital - located on Clinicilor Street, Cluj-Napoca CFR Hospital - on Republicii Street, etc.), but also due to its transit role, cultural institutions - "Lucian Blaga" Central University Library and Students' House of Culture -, events and shows and, rarely, due to its place memory.

The answers for Mihai Viteazul Square reflect the same main reason, i.e. its transit role. Other reasons were mentioned as well, such as the existence of bus stations, cinema, retail establishments, home proximity, and the generated urban atmosphere.

The Museum Square attracts visitors due to its dynamic nightlife, architecture, place memory and historic symbols, terraces and tourist sites, lack of motorised vehicles, the church, and fast-food restaurants. Ștefan cel Mare Square benefits from the National Theatre and the Romanian Opera proximity, alongside plenty of green areas and playgrounds (Fig. 13).
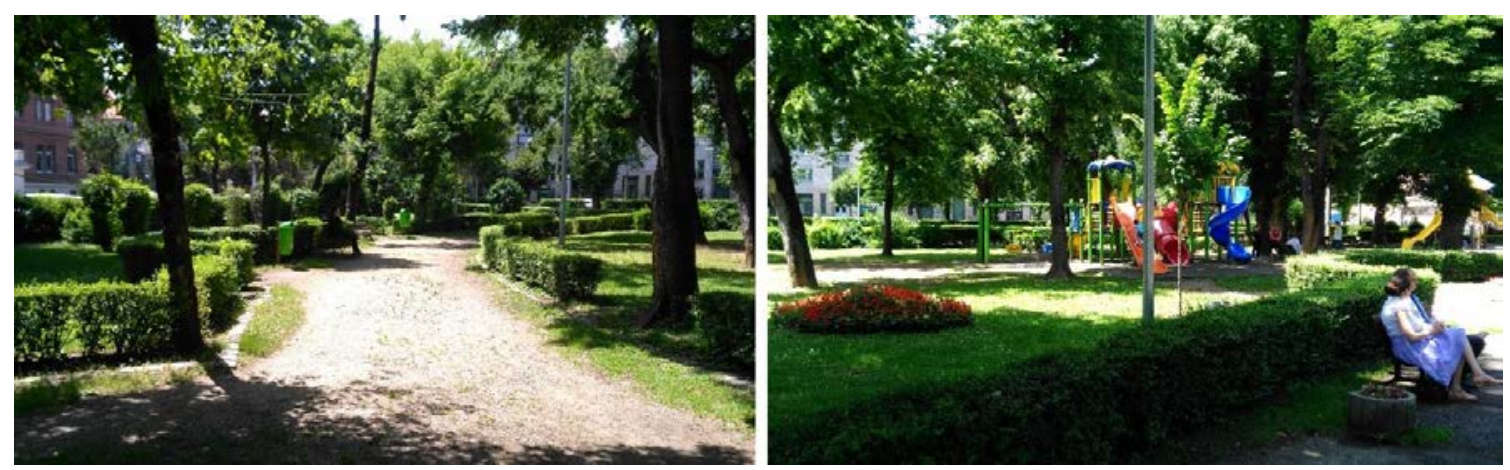

Figure 13: Pedestrian walkway made of ground and gravel. Playground equipment for children Source: Emanuel-Cristian ADOREAN, 2016 C

However, the Union Square attracts visitors due to its frequently hosted events (Fig. 14 and Fig. 16), its architecture and urban design, historic, cultural and religious monuments, recreational venues (Fig. 15), temporary outside retail establishments (Fig. 16) (for instance between the $1^{\text {st }}$ and the $8^{\text {th }}$ of March), but also due to its transit role, its urban atmosphere, or to its collective memory of place.
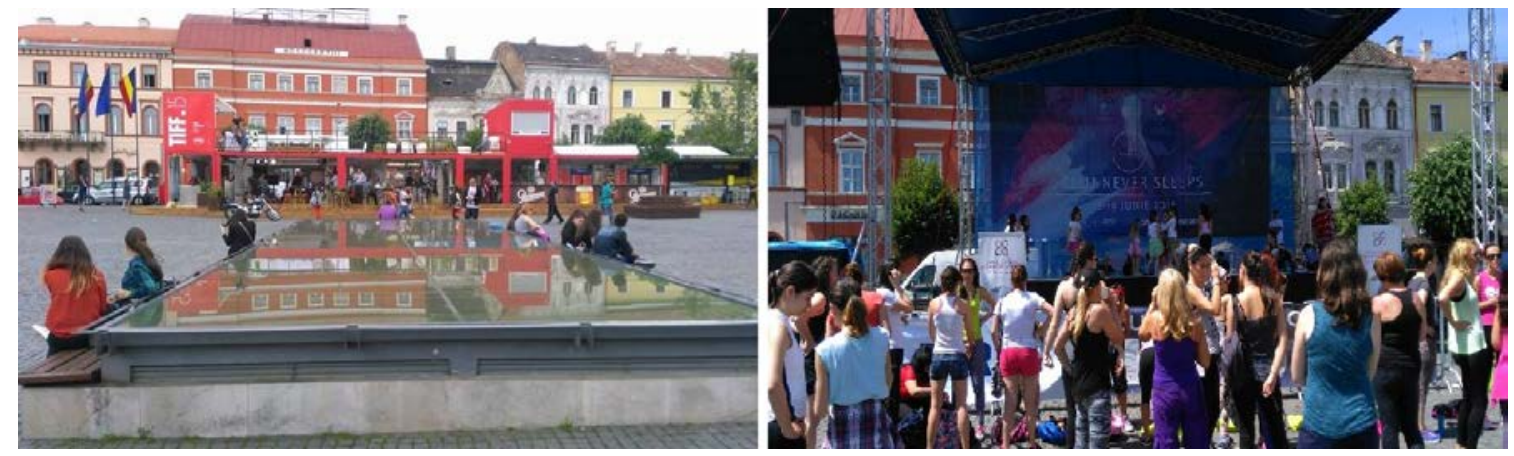

Figure 14: Transylvania International Film Festival location in the Union Square /

Dance show at Cluj Never Sleeps event

Source: Emanuel-Cristian ADOREAN, 2016C 


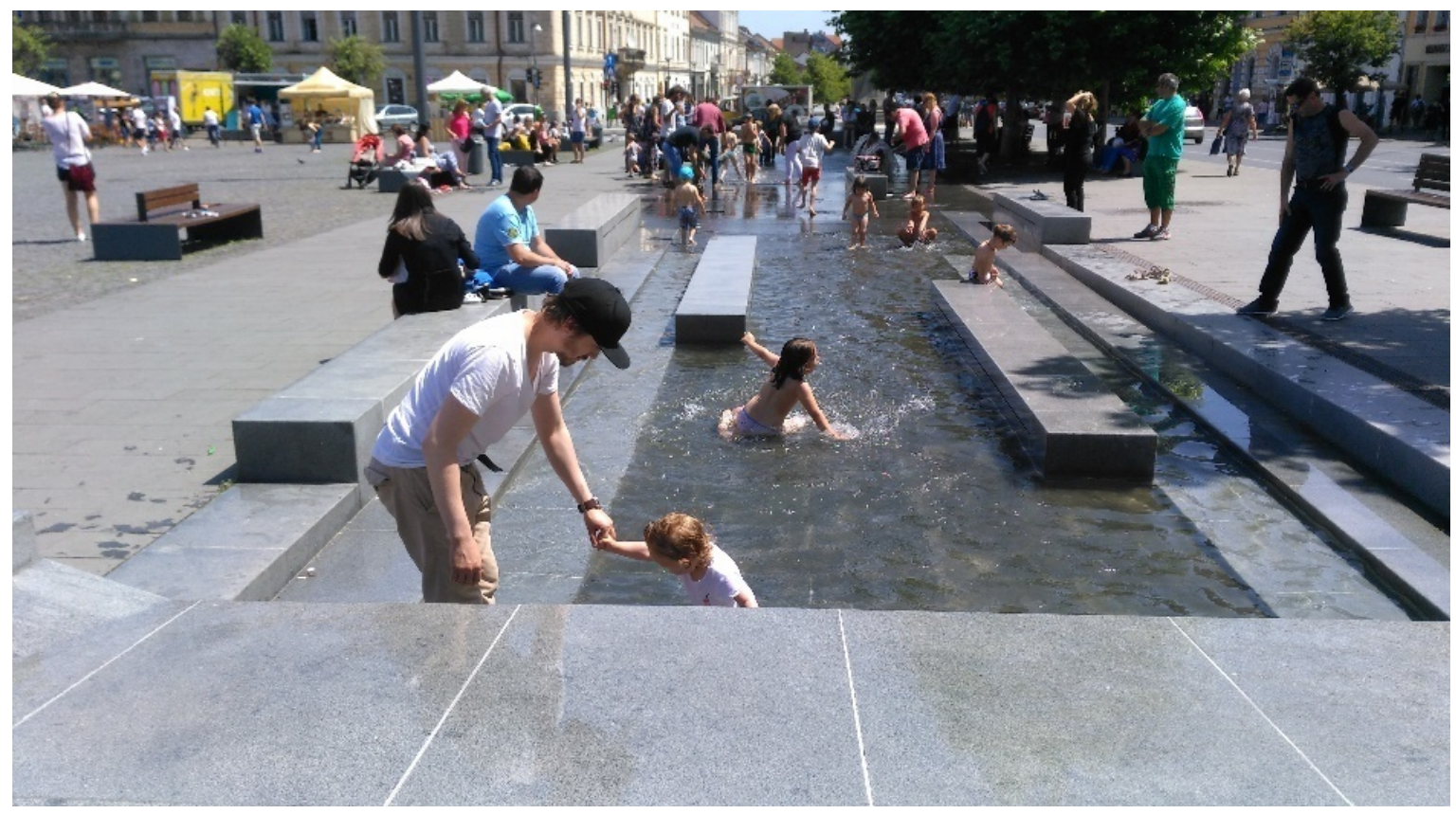

Figure 15: Specific activity during the hot days in the Union Square

Source: Emanuel-Cristian ADOREAN, 2016C

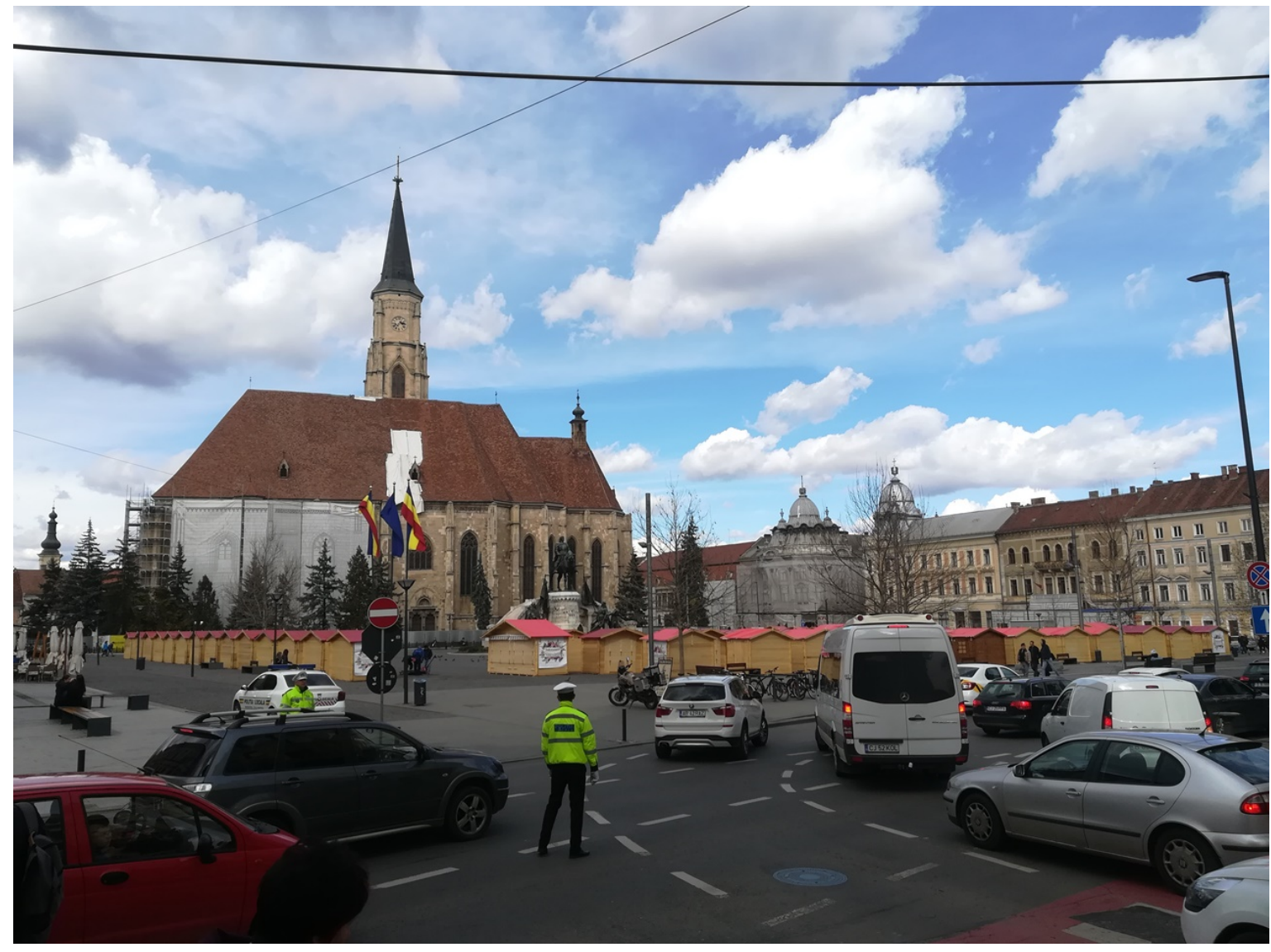

Figure 16: March fair with specific urban furniture and retail units in the Union Square Source: Alexandru-Sabin NICULA, 2019@ 


\section{Summing up the functions of central public squares}

The recreational function is the most significant and rather common for the central public squares of Cluj-Napoca: $38.33 \%$ of the respondents consider it the primary usage of the squares, followed by the cultural one $(26.66 \%)$. Significant weightings are given to the commercial, civic, religious, and symbolic ones. The recreational function was examined as being dominant first in Ștefan cel Mare Square, secondly in Avram lancu Square and Museum Square, next in Mihai Viteazul Square, in Union Square, and lastly in Lucian Blaga Square, respectively (this hierarchy was made according to the number of answers considering it dominant for each public square).

The cultural function is the most representative one for Lucian Blaga Square. The other squares, in order, are the following ones: Union Square, Ștefan cel Mare Square, Museum Square, Avram lancu Square, and Mihai Viteazul Square. On one hand, the commercial function is more figurative for Mihai Viteazul Square, followed by the Union Square, and the Museum Square. On the other hand, the civic function is highly prevalent in case of the Union Square, the religious function in Avram lancu Square, the symbolic function in Mihai Viteazul Square, the aesthetic function in Avram lancu Square, the historic function in the Museum Square, and the transit function in Lucian Blaga Square.

In our research, we focused on public squares as part of the public space and within these, among others, on the green area. The green area coefficient was calculated as ratio of the green area index (green area divided by the total square area) and the built area index (built area divided by the total area of the square). As a result of the calculation of squares green area index, it was found that Avram lancu Square had the largest green area related to the total square area (0.473), followed by Ștefan cel Mare Square (0.383) and Mihai Viteazul Square (0.240). On the contrary, the Museum Square (0.049), Lucian Blaga Square (0.084), and the Union Square (0.153) had the smallest green areas.

To sum up, this coefficient recorded low and average values which were also confirmed by the users' perceptions of the public squares green area. Considering the users' perceptions regarding the green area of each square, 128 people were satisfied, while another 121 people were unsatisfied. Avram lancu Square is ranked first, with $80 \%$ of the respondents saying they were satisfied with the green surface. Mihai Viteazul Square ranked second, with $62 \%$ of the respondents satisfied, next, the questionnaires applied to Ștefan cel Mare Square confirmed $56 \%$ of the surveyed users as being satisfied with the green surface; in case of Lucian Blaga Square, $22 \%$ of respondents declared themselves satisfied with the total surface of green area, and $68 \%$ unsatisfied and very unsatisfied. Furthermore, the Union Square was prevalent for the unsatisfied (44\%) and very unsatisfied (24\%) users and, finally, according to the answers, the Museum Square was the most disadvantaged in terms of green area surface, $78 \%$ of the surveyed users being unsatisfied and very unsatisfied.

The recreational function prevails in the central open squares of Cluj-Napoca as their key role, as it has been mentioned by $38.33 \%$ of the interviewees, followed by their cultural function, with $26.66 \%$ of the respondents. In addition, their civic, religious and symbolic functions also registered significant percentages. 


\section{Malfunctions}

Avram lancu Square is characterised by agglomeration and car transit, in addition to the presence of beggars in this space, the lack of shade in the warm season, the height of the statue that obliges the admirer to a greater visual effort, or the presence of edifices that hinder the aesthetic aspect of the square (for example the "ghost spaces" located on the western side - Fig. 17).

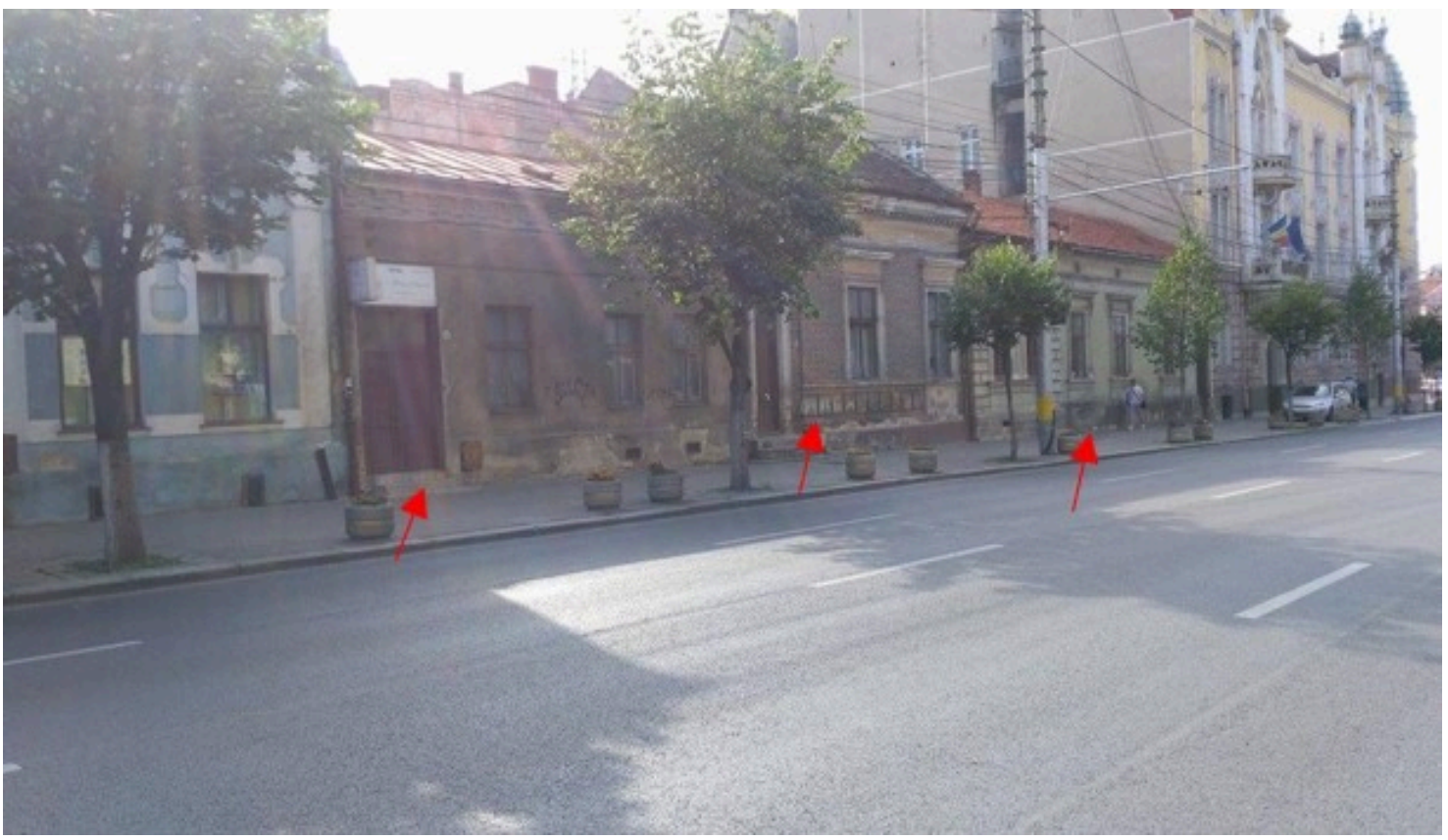

Figure 17: "Phantom spaces" in Avram lancu Square Source: Emanuel-Cristian ADOREAN, 2016৫

Lucian Blaga Square features intensive daytime crowding and traffic, noise, beggars, lack of parking places, the presence of buildings built according to the "Communist pattern" or the poor size of urban furniture.

Mihai Viteazul Square displays degraded urban furniture, as a consequence of inappropriate use, and lack of satisfactory level of cleanliness. In addition, the growing degradation of the statue, of the monument over which it is located and of the pavement show low interest of local authorities in the viability of this public space; as such, the deterioration process is in full swing. Added, the quite intensely motorized transit during the day, the noise, the beggars or street people.

Museum Square copes with summer crowds, relatively small size, high prices of the venues compared to the rest of the city, contrast between "fast food" and "ghost spaces" (degraded or unused buildings), respectively the antithesis between modern and old or degraded buildings, unsightly urban art (graffiti), inefficient sanitation service, seasonality and drug use.

Ştefan cel Mare Square is affected by motorized crowding and traffic, nocturnal market image, inefficient sanitation service, alleys becoming impracticable after rain, alcohol drinkers, beggars and street people, and by the degradation of urban furniture, accelerated by its inappropriate use.

Union Square is characterised by vehicle noise, low green space, poorly pitched pavement, lack of privacy and "exaggerated modernism". 
Experiencing the cultural landscapes of the urban public space in Cluj-Napoca

Gallion \& Eisner (1980, p. 395) emphasized that: "[t]he 'billboard syndrome' defaces strip commercial streets in every city [...] power poles and wires, competing traffic signals, a convulsive mass of distracting color, form and motion, obscure the identity of individual signs. Every street looks every other street; in the words of Gertrude Stein, 'When one gets there, there is no there there'". In this respect, the authors of Vernacular and Technology. InBetween propose an extensive analysis on "understanding the landscape as human's life framework, as natural and cultural resource" (Hărmănescu \& Enache, 2016, p. 412). As such, "[a]s well as being located and having a material visual form, places must have some relationship to humans and the human capacity to produce and consume meaning" (Cresswell, 2004, p. 7). At the same interpretative level, Sauer's morphological approach advances the idea of 'cultural outcomes' as landscape traces, focusing rather on the individuals' material artefacts in the landscape (Sauer, 2008).

Considering these theoretical approaches and inhabitants' perceptions, the places and cultural landscapes of Cluj-Napoca central public squares may be easily included in the category of authentic cultural products. However, the mixture of forms, new phenomena, tendencies, and needs has its impact on the landscape. Therefore, the role of this mixture is to find a solution to the spatial contradictions, dysfunctions, and to ensure the continuity of the fabric, the consistency of the urban image, the functional connectivity, and of the social and urban identity.

Along the postmodern debate over the cities developing a 'symbolic economy', Zukin explores culture as a means of urban governance, which involves the private-public partnership (Zukin, 2008). She also advocates that culture is "a powerful means of controlling cities" (Zukin, 2008, p. 432) of adjusting spaces of inclusion and exclusion, besides controlling collective memory, by taking into consideration what landmark of the urban landscape will be preserved as heritage or restored as visual: "So the symbolic economy features two parallel production systems that are crucial to a city's material life: the production of space, with its synergy of capital investment and cultural meanings, and the production of symbols, which constructs both a currency of commercial exchange and a language of social identity. Every effort to rearrange space in the city is also an attempt at visual re-presentation. Raising property values, which remains a goal of most urban elites, requires imposing a new point of view. But negotiating whose point of view and the costs of imposing it create problems for public culture. Creating a public culture involves both shaping public space for social interaction and constructing a visual representation of the city" (Zukin, 2008, p. 438).

Further, in his book, Relph (2008) proposes that the inauthentic attitude on place making is the essential root of the placeless environment. Placelessness is just a distinct sequence in building the environment, reinforcing new consciousness of place, revealing its own ontology. This latter one manifests itself as a new use of space. The inauthentic attitude on urban place making determines "no awareness of the deep and symbolic significance of places" and "no appreciation of their identities" (Relph, 2008, p. 82). There are two fundamental arguments behind this type of attitude, which are interwoven to each other on placeless urban revitalization: unself-conscious or 'kitsch' - "places treated as things" (Relph, 2008, p. 83) and self-conscious or 'technique' - "places treated as (uniform) spaces" (Relph, 2008, p. 87). Following, the production of places is devised in a stereotypic manner to be consumed by the public and manipulated by mass public interest.

Taking into consideration the present urban context, the modern individual refuses uniformization, although apparently this 'placelessness' - "the casual eradication of distinctive places and the deliberate making of standardized landscapes and the weakening of the identity 
of places to the point where they both look alike and offer the same bland possibilities for experience. It is less deliberate and more subtle than place destruction" (Relph, 2016) - leads to this direction, the city centre acquires new functions, despite the impact/effect of territorial hybridization on urban identity, and the public space becomes the symbol of urban cohesion. $\mathrm{He}$ goes one step forward by stating that "placelessness is not merely in the context of the presentday landscapes - it is an essential part of them and a product of them" (Relph, 2008, p. 139).

The discourses above about place and placelessness, about authenticity, kitch and lack of territorial identity, about the production of space and the production of symbols, about new functional spaces and urban renewal enable understanding of recent urban transformations and challenges and an understanding of their impact (social, economic, cultural, and psychological). Changes in urban functions and landscape transformations in Cluj-Napoca historic centre and public space are reflected in the present hybrid places and hybrid cultural landscapes: old hybrid cultural landscapes (associating valuable historic buildings with new/modern functions) and new hybrid cultural landscapes (modern buildings inserted among heritage buildings) (Table 2).

Table 2: Hybrid cultural landscapes - outlining the territorial expression of Cluj-Napoca city centre

\section{OLD HYBRID CULTURAL LANDSCAPE}

Old buildings with headquarters of financial and banking units: Memorandumului St., Eroilor/Heroes Blvd., Moţilor St., Union Sq., King Ferdinand St., Republicii St., Horea St., etc.

Second-hand shops / outlets: Napoca St., University St., Memorandumului St., Heroes Blvd., Mihai Viteazul Sq., Avram lancu Sq., Horea St.

Sales Units / Mobile Equipment Repair: Eroilor Blvd., Memorandumului St., 21 December 1989 Blvd., Mihai Viteazul Sq.

Buildings or spaces arranged in public catering buildings: Lucian Blaga Sq., Mihai Viteazul Sq., 21 December 1989 Blvd., Piezişă St., Napoca St., Eroilor Blvd., University St., King Ferdinand St., Museum Sq., Horea St., George Bariţiu St., Emil Isac St., Iuliu Maniu St., etc.

Shopping Centres: Sora Shopping Centre (21 December 1989 Blvd.), Central (King Ferdinand)

\section{NEW HYBRID CULTURAL LANDSCAPE}

New branches of banking units: BCR Branch, Transilvania Bank (George Bariţiu St.), Bancpost (Mihai Eminescu St.), BRD Groupe Société Générale (21 December 1989 Blvd.)

Offices / Business Parks: Maestro Business Centre, Cluj Office (21 December 1989 Blvd.), City Business Centre (Cuza Vodă St.)

Car Parking: Multiplex Leu (Mihai Viteazul Sq.), City Hall (Lucian Blaga Sq.)

Modern residential complexes, new hotels and public catering buildings: Platinia Elite Residence (Mănăștur Way), Alexis Hotel (Dorobanților Way), Havana Restaurant (Mihai Viteazul Sq.), Beyfin Hotel (Avram lancu Sq.), Club 69 Restaurant (Piezișă St.), etc.

Mall Shopping Centres: Platinia Shopping Centre (Mănăștur Way)

Managing such a living cultural landscape - be it designed, evolving, or associative - has attracted a lot of scholarly attention lately. The paradigm of urban regeneration can be understood as a new challenge faced by the symbolic and functional power of places, in terms of cultural identities, that is of outstanding significance. This directly and intensely manifests about how the landscape decodes its core status, in the area of cultural heritage management and policy making related to development in the form of urban comprehensive planning (Sandström et al., 2006, p. 43), giving a new perspective for future projects, under what has been coined as "urban acupuncture": "In time, urban scars may be transformed into a new landscape. Making the best of these new landscapes and repairing man's blunders requires nothing less than the best sort of acupuncture" (Lerner, 2014, p. 3). Therefore, these interventions should be based on the site's specificity (e.g. old hybrid cultural landscape in Fig. 18 and Fig. 19). 


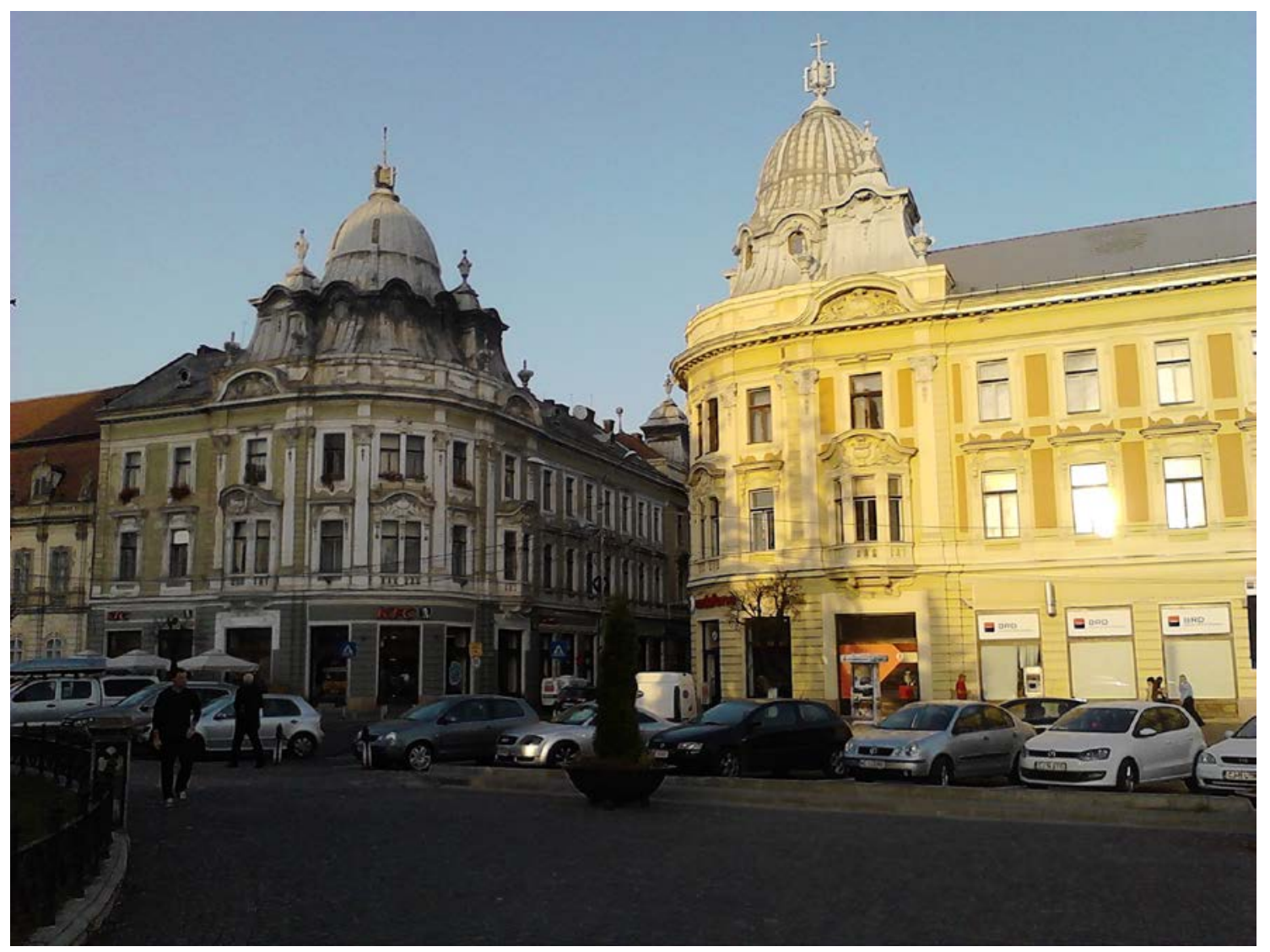

Figure 18: Old hybrid cultural landscape in the Union Sqaure - The "Twin" Baroque eclectic style buildings of the Roman-Catholic Statuses having commercial façade on their ground floor Source: Zoltan MAROȘI, 2016@

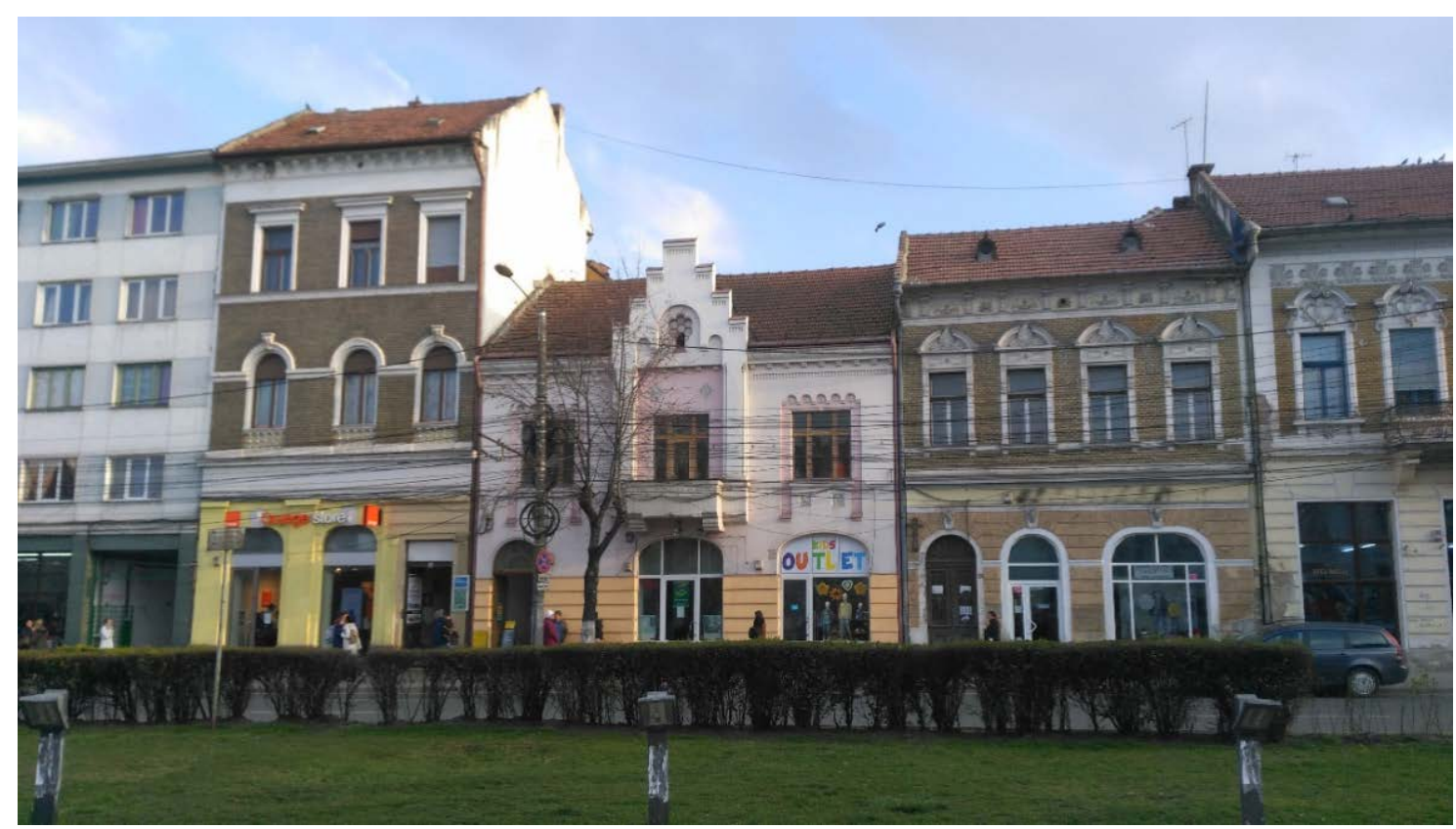

Figure 19: Old hybrid cultural landscape in Mihai Viteazul Square - A complex of buildings with heterogeneous architectural styles and typical urban function 
It is acknowledged that public spaces play a key role in residents' everyday life. According to Sharma (2014), there is outsideness "expressed as a feeling of separation between a person and place, whereas insideness is defined as a sensation that emphasizes the connection with place" (p. 30). Therefore, these changing cultural landscapes convey the layered stories of people, events and places, allowing a sense of continuity. They also represent the evidence of a cultural context setting, as well as of a social-community dimension for their material cultural heritage. Considered to be inevitable but necessary, appropriate or inappropriate, the 'new' has always been the challenging element of any reinterpretation of urban architecture. The structure of the place within the urban context, all of which is highlighted by cultural, social, identitarian, historical, political values, will sooner or later be threatened by transformations, revitalization, overlapping, or reconfiguration.

Similarly, the urban cultural landscapes of these squares are the lively reflection of the versatile urban identity. As such, the urban change is a necessary process, resulting in newly created hybrid landscapes, a form of hybrid cultural identities representation (Fig. 20 and Fig. 21).

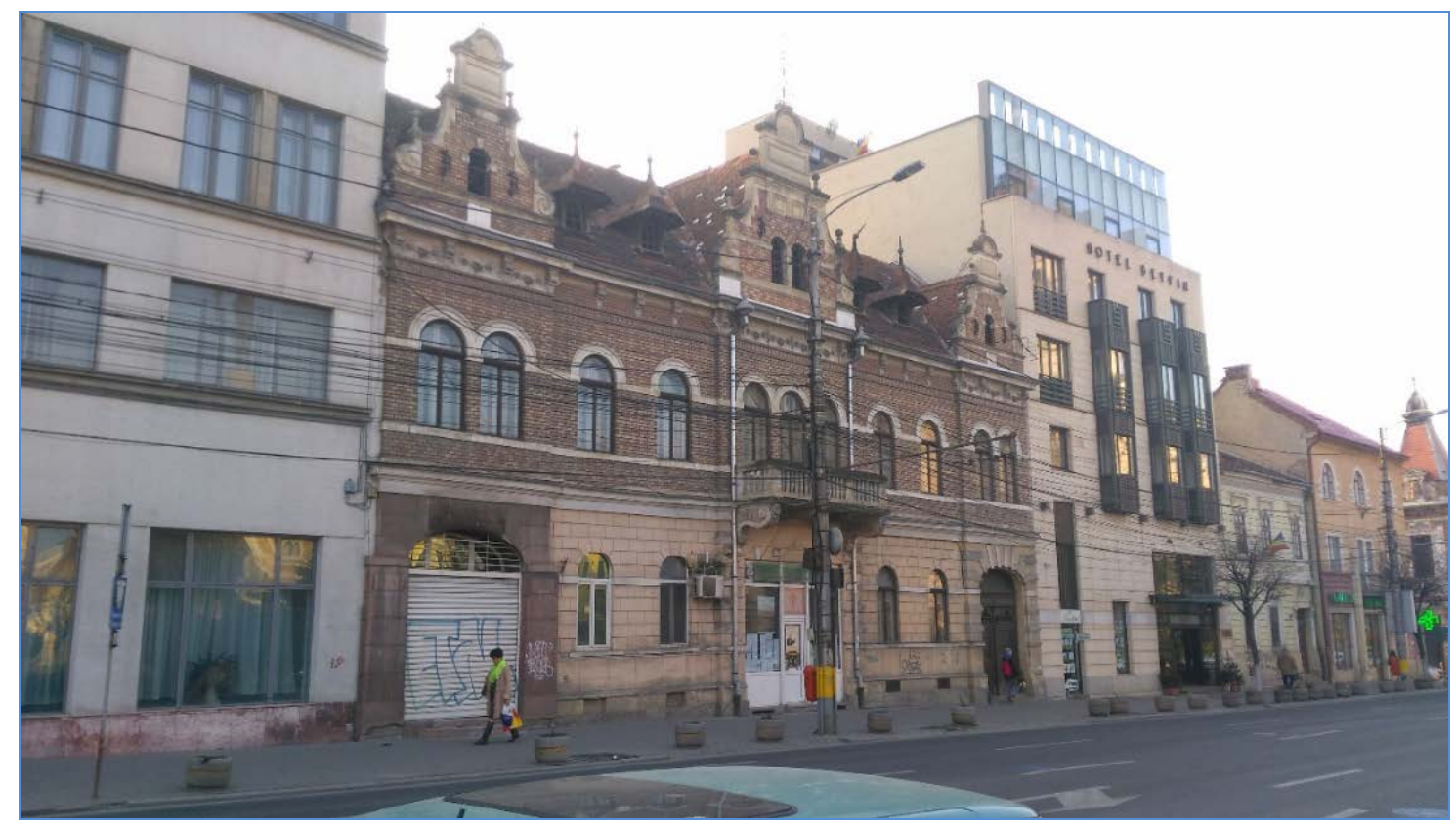

Figure 20: New hybrid cultural landscape in Avram lancu Square - Contemporary civil engineering insertions into old town architecture 

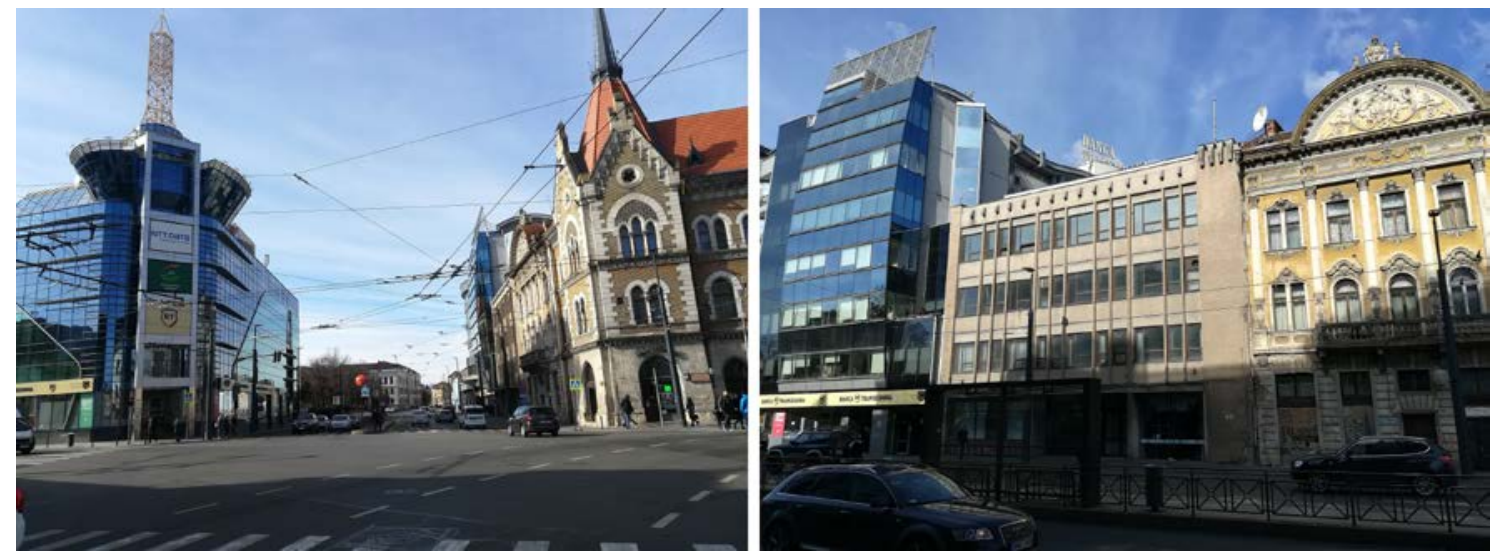

Figure 21: New hybrid cultural landscape in the proximity of Mihai Viteazul Square

Source: Alexandru-Sabin NICULA, 2019@

Recently, in the current literature review, most scholars have acknowledged the beneficial effects of urbanization, thus supporting the extensive urban governance and advanced enlargement rather than substantial demolition and reconstruction (Maimunah et al., 2015). In case of Cluj-Napoca, the historic urban centre hosts many retail commercial activities, but especially simple commercial and residential areas (second-hand, industrial and chemical products shops, betting shops, and very old residential areas). This diminishes considerably the landscape value, alongside the degraded, abandoned or badly refurbished buildings (which after refurbishing are more damaged than repaired, because of improvisations) (Fig. 22).
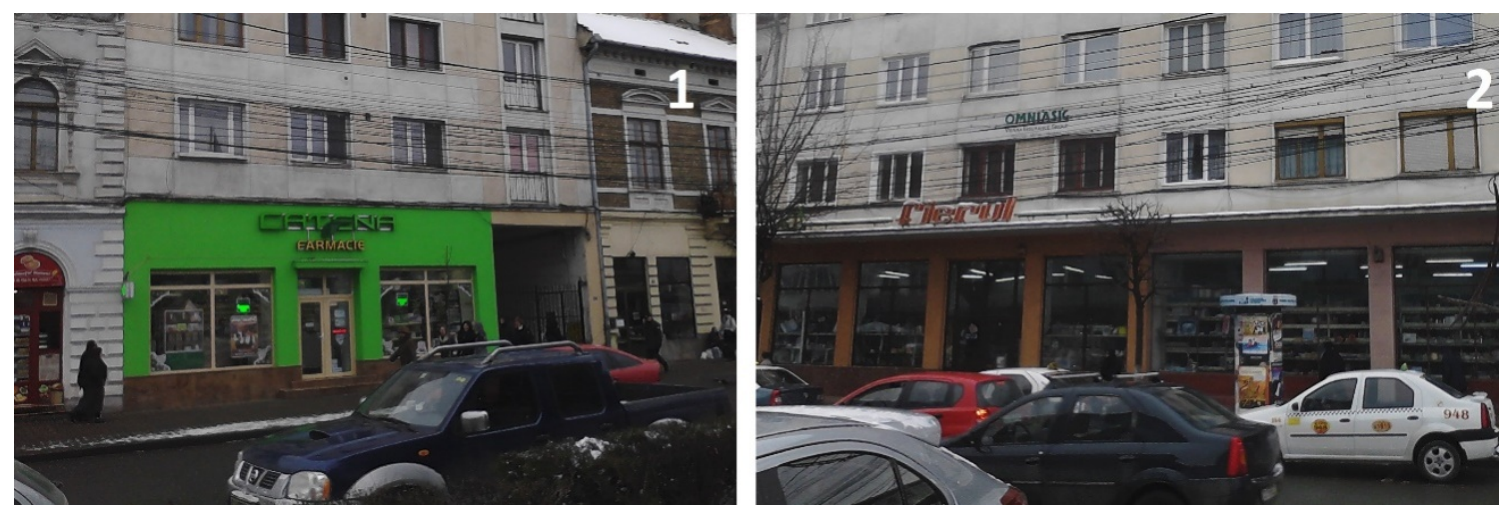

Figure 22: Residential buildings with low wealth commercial activities on the ground floor in Mihai Viteazul Square. 1 - unaesthetic refurbished façade; 2 - industrial, and chemical products shops with the Communist commercial logo intact

Source: Zoltan MAROȘI, 2016 C

Closely related to the (re)construction of newly functional spaces, the urban renewal / revitalization is mainly a result of social and economic pressures. Thereby, when addressing an intervention at the urban level, it is needed to understand that although residents may wish to preserve the fabric and feeling of their traditional built environment, owners may feel under pressure to maximize their comfort and the potential of their properties and not necessarily the historical structures on them, which often involves higher costs to maintain or preserve rather than to completely rebuild them. The transformation or reconversion of historical buildings to modern comfort and safety standards is also a very problematic issue, doubled by numerous regulations and high bureaucracy (often avoided by the citizens of Romania). This results in the demolition of entire historical surroundings, or at best, slow attrition (Fig. 23), as 
one building after another is replaced by modern, high-return development (i.e. malls, fast food restaurants such as KFC, McDonald's, Subway, store fronts, bars, cafés, etc.).
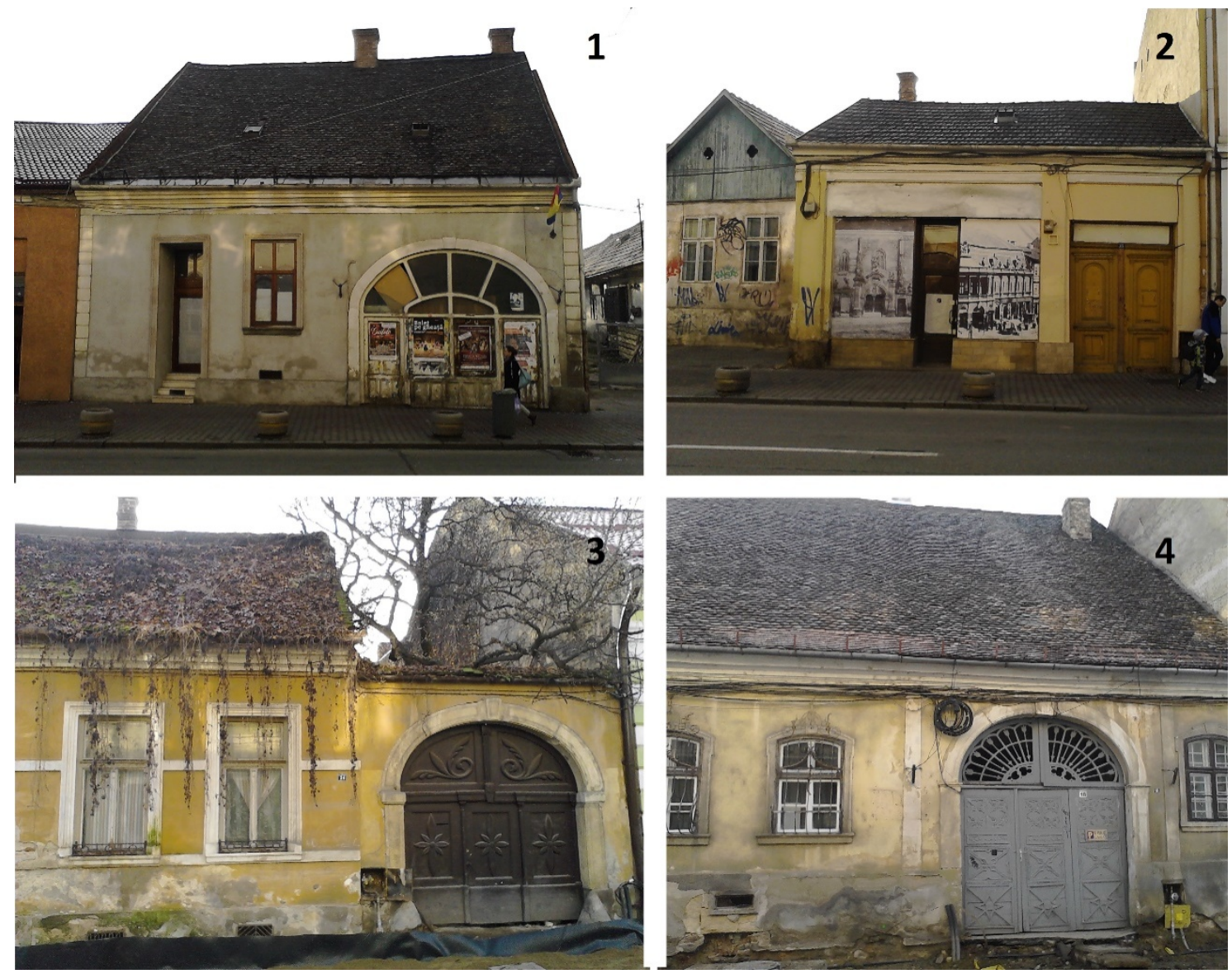

Figure 23: Degraded historical buildings. 1, 2 - Nearby Lucian Blaga Square and

3, 4 - Nearby Avram lancu Square

Source: Zoltan MAROȘI, 2016৫

\section{Proposals to reduce existing malfunctions - priority objectives}

Following the assessment of the existing situation on the central squares of Cluj-Napoca, it was found that each square has its own identity and, at the same time, each square is affected by specific malfunctions, therefore it is strictly necessary to establish a viable solution line for remedying the dysfunctions for each individual case. Thus, in order to improve the functionality and quality of urban squares in the central perimeter of the city, a priority framework has been developed containing proposals for urban regeneration and landscaping to combat the weaknesses signaled through territorial diagnosis (Table 3).

The solutions related to improving the quality of the public space of Avram lancu Square aim at removing parking lots from the side of the square, decongesting road traffic by closing down some traffic lanes at certain times of the year, upgrading and preserving the current shape of buildings either by changing the category of use or by creating a new function. 
Lucian Blaga Square requires a wide range of measures: decongesting traffic, blocking a traffic road, increasing the size of green spaces, and introducing urban furniture pieces (as visitor density is very high, especially during the academic year). Subsequently, proposals can be added to strengthen its authenticity and cultural valences - organizing shows, workshops, photographic competitions, urban and street art competitions, etc.

Table 3: Goals to reduce existing malfunctions

\begin{tabular}{|c|c|}
\hline SQUARE & PRIORITY SOLUTIONS \\
\hline Avram lancu & $\begin{array}{l}>\text { "Ghost spaces" removal } \\
>\text { Traffic decongestion } \\
>\text { Introducing bike rasters } \\
>\text { Car parks removal on the eastern and western sides of the square }\end{array}$ \\
\hline Lucian Blaga & $\begin{array}{l}\text { Traffic decongestion Green space enlargement } \\
\quad \text { Introducing new pieces of urban furniture (seating and garbage bins) } \\
\text { Blocking at least one traffic lane }\end{array}$ \\
\hline Mihai Viteazul & $\begin{array}{l}>\text { Monument and statue rehabilitation } \\
>\text { Pavement replacement } \\
>\text { Sitting benches replacement } \\
>\text { Blocking at least one traffic lane } \\
>\text { Sanitation system efficiency } \\
>\text { Upgrading the artesian fountain } \\
>\text { Information panel }\end{array}$ \\
\hline Museum & $\begin{array}{l}>\text { "Clone spaces" and "ghost spaces" removal } \\
>\text { Sanitation system efficiency } \\
>\text { Information panel }\end{array}$ \\
\hline Ștefan Cel Mare & $\begin{array}{l}\text { Sanitation system profitability } \\
\quad \text { Paving the square, in a sustainable (environmentally friendly way) } \\
\text { Remove parking spaces at least on two sides of the square Efficiency } \\
\text { of the night street lighting system Sitting benches replacement }\end{array}$ \\
\hline Union & $\begin{array}{l}\text { Sanitation system efficiency } \\
>\quad \text { Introducing bike rasters } \\
>\quad \text { Traffic blocking at least on an artery, preferably the western one } \\
>\quad \text { Reducing noise by introducing dense vegetal curtains } \\
>\quad \text { "Clone spaces" removal }\end{array}$ \\
\hline
\end{tabular}

Mihai Viteazul Square requires intensive restructuring (pavement, sitting benches, artesian fountain) and renovations for the statue and the monument. The overall disadvantage of this space will be diminished if considering the requirements to improve the sanitation system, to eliminate visual pollution by planting vegetal curtains on the western side, to decongest traffic and to capitalize on its cultural and historical attributions - introducing an informative panel, organizing shows or events with a focus on activating local identities through collective memory, thus avoiding the attendance of this space and improper use by homeless and beggars who jeopardize its functionality.

Museum Square needs a regular and proper sanitation system, eliminating drug use, rehabilitating degraded buildings and eliminating functions that favour the existence of "clone spaces", which, as far as possible correlated with a better capitalization of the historical built heritage, would lead to more enhanced public space. 
To a large extent, Ştefan cel Mare Square needs the replacement of urban furniture, the efficiency of the garbage collection system, the profitability of the street lighting system during the night, and the reduction of the noise by motorized traffic streamlining to disseminate the malfunctions.

Union Square requires improving the sanitation service, streamlining traffic and reducing noise by planting shrubs (this way the lack of shade in the hot season is solved).

Among these proposals, the central area could set up a "route of the historical squares in Cluj", which would value the specifics of these public spaces, the heritage, religious, recreational, tourist buildings, their functionality and, last but not least, the urban design of these areas.

\section{CONCLUSIONS}

Despite their metamorphoses suffered over time, urban public spaces continue to represent the only places where the occurrence of collective life lies in full comfort zone. The city life quality or residents' welfare can be estimated by the versatility of collective life that is expressed in urban public spaces.

The current trend across the entire European continent is to redefine public space through modern urban design, which entails the creation of a sustainable environment. It means that we can design areas / spaces / territories that are safe, where people want to live, work or spend their spare time and which will inevitably polarize more categories of users.

In this paper, we analysed the symbolic and functional public spaces of Cluj-Napoca city centre, focusing on the features and functions of the central squares, employing a mixed research methodology (quantitative and qualitative) and especially paying attention to inhabitants' perceptions of these areas and the related quality of life. Our aim was to find the most appropriate solutions to solve the underlying malfunctions through territorial diagnosis.

As the most representative categories for the city's public space, due to the multidisciplinarity of the valences they engage, the historical squares in the central Cluj-Napoca area are different both in form, profile, size and structure, as well as functional attributes. There is a change in the functions of squares, along with the evolution of the city, from the economic or commercial function to the recreational or cultural one.

The assessment of the existing situation reveals the need to impose landscape regeneration measures based on criteria that provide a higher degree of functionality of the squares and of the central space itself, without excluding the use of urban facilities and their currently held characteristics.

Visiting public spaces is an optional activity dictated primarily by their functionality. The user profile highlights, on the one hand, the centripetal character of the city, including the central area, and, on the other hand, it highlights the ethnic, social, cultural or behavioural heterogeneity it benefits from. The users' perception about the endowments and the functionality of the squares generates a logical contradiction between their statements and behaviour. Even if in many cases they are dissatisfied with some aspects of public space quality, they continue to use that space, sometimes necessarily, sometimes out of the ordinary.

The present study can provide complete results for all researchers wishing to deepen this issue, or, on the contrary, can only mark the starting point for other scientific investigations within this field. 


\section{REFERENCES}

A.N.T / N.A.T. [Autoritatea Națională pentru Turism/National Authority for Tourism] (2015).Piețe istorice și zone pietonale [Historical Squares and Pedestrian Areas], Retrieved June 5 2016, from http://turism.gov.ro/wpcontent/uploads/2013/05/brosura-piete-EN.pdf

ADOREAN, E.-C. (2016). Designul urban și funcționalitatea spațiului public central al Municipiului Cluj-Napoca. Lucrare de licență [Urban Design and the Functionality of Cluj-Napoca City. Bachelor's Thesis]. Faculty of Geography, Babeș-Bolyai University.

AGACHI, M.I.M. (2009). Clujul modern. Aspecte urbanistice [Modern Cluj. Urbanistic Aspects], 2nd edition. ClujNapoca: U.T. PRESS.

BOLOG, C., \& MATHE, A. (2015). Îmbinarea realului cu virtualul ca perspectivă pentru dezvoltarea turismului urban în Cluj-Napoca [Mingling the Real with the Virtual as a Perspective on Developing Urban Tourism in ClujNapoca]. Geographia Napocensis, IX(2), 83-92.

BRENNER, N., \& SCHMID, C. (2015). Towards a New Epistemology of the Urban? City, 19(2-3), 151-182. DOI: $10.1080 / 13604813.2015 .1014712$

CARMONA, M., HEATH, T., OC, T., \& TIESDELL, S. (2003). Public Spaces - Urban Spaces: The Dimensions of Urban Design. Oxford: Architectural Press.

CIORCA, I. (2012). Piaţa Lucian Blaga [Lucian Blaga Square]. Retrieved May 10 2016, from http://www.clujtoday.ro/2012/10/21/piayua-lucian-blaga.html

CRESSWELL, T. (2004). Place: A Short Introduction. Coventry: Blackwell Publishing.

CULLEN, G. (2010). Paisagem Urbana [Urban Landscape]. Lisboa: Edições 70.

DECREE no. 194/1974 privind atribuirea denumirii Cluj-Napoca municipiului Cluj publicat în Buletinul Oficial al RSR, Nr. 125, vineri, 18 octombrie 1974 [Decree on Changing the Name of Cluj Municipium to Cluj-Napoca], $\begin{array}{llll}\text { Retrieved } \quad \text { February } & 5 & \text { 2018, from }\end{array}$ https://upload.wikimedia.org/wikipedia/commons/8/8b/Napocirea_Clujului.jpg

DULAMĂ, M.E., MAROŞI, Z., \& ILOVAN, O.-R. (2016). Chapter 3: Geography University Education for the Protection and Capitalisation of Cultural Urban Landscapes. A Case Study: The Museum Square, Cluj-Napoca, Romania. In Ilovan, O.-R., Dulamă, M.E. (eds.), Territorial Identity and Values in Geographical Education (pp. 59-118). Cluj-Napoca: Presa Universitară Clujeană.

EUROPEAN COMMISSION (2013). Quality of Life in Cities. Perception Survey in 79 European Cities. Regional and Urban Policy. Luxembourg: Publications Office of the European Union. DOI: 10.2776/79403

GALLION, A. B., \& EISNER, S. (1980). The Urban Pattern: City Planning and Design. New York: D. Van Nostrand Company.

GEHL, J., \& SVARRE, B. (2015). Cum se studiază viața urbană [The Way to Study Urban Life]. București: Igloomedia.

HĂRMĂNESCU, M., \& ENACHE, C. (2016). Vernacular and Technology. InBetween. Procedia Environmental Sciences, 32, 412-419.

LERNER, J. (2014). Urban Acupuncture: Celebrating Pinpricks of Change that Enrich City Life. Washington DC: Island Press.

LYNCH, K. (2011). A imagem da cidade [The Image of the City]. Lisboa: Edições 70.

MAIMUNAH, R., DASIMAH, O., ROZIAH, M.Y., \& ZALINA, S. (2015). Revitalization of Urban Public Spaces: An Overview. Procedia - Social and Behavioral Sciences, 201, 360-367.

MAROŞI, Z. (2015). Peisaje culturale în centrul istoric al Municipiului Cluj-Napoca. Lucrare de disertație [Cultural Landscapes in the Historical Centre of Cluj-Napoca City. Master's Thesis]. Faculty of Geography, Babeș-Bolyai University.

MAROȘI, Z., ADOREAN, E.-C., ILOVAN, O.-R., GLIGOR, V., VOICU, C.-G., NICULA, A.-S., \& DULAMĂ, M.E. (2019). Living the Urban Cultural Landscapes in the City Centre of Cluj-Napoca/ Kolozsvár/ Klausenburg, Romania. Mitteilungen der Österreichischen Geographischen Gesellschaft, 161 (under print).

MISHU, M.R., BARUA, U., \& STOICAN, I.-A. (2014). The Changing Nature of Urban Public Places in Dhaka City. Urbanism Architecture Constructions, 5(4), 5-16. 
MOLDOVAN, M., \& PURCAR, C. (2012). Piețele urbane ca peisaje. Elemente de analiză vizuală [Urban Public Spaces as Landscapes. Elements of Visual Analysis]. Cluj-Napoca: U.T. Press.

NARCISO, C.A.F. (2009). Espaço público: ação política e práticas de apropriação. Conceito e procedências [Public Space: Political Action and Appropriation Practices. Concept and Origins]. Estudos e Pesquisas em Psicologia, 9(2), 265-291.

PAILLIART, I. (2002). Spațiul public și comunicarea [Public Space and Communication]. Iași: Polirom.

PASCU, Șt. (1975). Istoria Clujului [History of Cluj]. Cluj-Napoca: Consiliul Popular al Municipiului Cluj.

RELPH, E. (2008). Place and Placelessness. London: Sage.

RELPH, E. (2016). Overview of Anti-Place Ideas. In Placeness, Place, Placelessness, Retrieved February 5 2018, from http://www.placeness.com/2016/01/

SANDSTRÖM, U.G., ANGELSTAM, P., \& KHAKEE, A. (2006). Urban Comprehensive Planning - Identifying Barriers for the Maintenance of Functional Habitat Networks. Landscape and Urban Planning, 75(1-2), 43-57. DOI: https://doi.org/10.1016/j.landurbplan.2004.11.016

SARADJ, F.M. (2016). Compatible Development Solutions in the Context of Historical Settings in Iran. Urbanism Architecture Constructions, 7(4), 285-300.

SAUER, C. (2008). "The Morphology of Landscape" from University of California Publications in Geography2, 2 (1925): 19-54. In Oakes, T.S., Price, P.L. (eds.), The Cultural Geography Reader (96-104). New York: Routledge.

SHARMA, M. (2014). Architectural Design Quality in Local Authority Private Finance Initiative Sheltered Housing Projects: The Development of an Evaluation Tool. PhD Thesis, University of Northumbria, available at Retrieved February 5 2018, from http://nrl.northumbria.ac.uk/21596/

SPENCER-OATEY, H. (2012). What Is Culture? A Compilation of Quotations. GlobalPAD Core Concepts, Retrieved April 15 2018, from https://warwick.ac.uk/fac/soc/al/globalpad/openhouse/interculturalskills/global_pad__what_is_culture.pdf

VÂLCEANU, D.-G., KOSA, R.-A., \& TĂMîRJAN, D.-G. (2014). Urban Landscape as Palimpsest. Urbanism Architecture Constructions, 5(4), 17-26.

VIERO CRESTANI, V., \&BARBOSA FILHO, L.C. (2009). Praças públicas: origens, conceitos e funções [Public Squares: Origins, Concepts, and Functions]. Jornada de Pesquisa e Extensão, ULBRA - Santa Maria, 1-3, Retrieved February 5 2018, from http://www.ceap.br/material/MAT1511201011414.pdf

ZUKIN, S. (2008). “Whose Culture? Whose City?” from The Cultures of Cities (1995). In Oakes, T.S., Price, P.L. (eds.), The Cultural Geography Reader (431-438). New York: Routledge. 